\title{
Origin of oxidized mercury in the summertime free troposphere over the southeastern US
}

\author{
V. Shah ${ }^{1}$, L. Jaeglé ${ }^{1}$, L. E. Gratz ${ }^{2}$, J. L. Ambrose ${ }^{3, a}$, D. A. Jaffe ${ }^{1,3}$, N. E. Selin ${ }^{4}$, S. Song ${ }^{4}$, T. L. Campos ${ }^{5}$, F. M. Flocke ${ }^{5}$, \\ M. Reeves ${ }^{5}$, D. Stechman ${ }^{5}$, M. Stell ${ }^{5}$, J. Festa ${ }^{6}$, J. Stutz ${ }^{6}$, A. J. Weinheimer ${ }^{7}$, D. J. Knapp ${ }^{7}$, D. D. Montzka ${ }^{7}$, \\ G. S. Tyndall ${ }^{7}$, E. C. Apel ${ }^{7}$, R. S. Hornbrook ${ }^{7}$, A. J. Hills ${ }^{7}$, D. D. Riemer ${ }^{8}$, N. J. Blake ${ }^{9}$, C. A. Cantrell ${ }^{10}$, and \\ R. L. Mauldin III ${ }^{10,11}$ \\ ${ }^{1}$ Department of Atmospheric Sciences, University of Washington, Seattle, WA, USA \\ ${ }^{2}$ Environmental Program, Colorado College, Colorado Springs, CO, USA \\ ${ }^{3}$ School of Science, Technology, Engineering and Mathematics, University of Washington-Bothell, Bothell, WA, USA \\ ${ }^{4}$ Department of Earth, Atmospheric and Planetary Sciences, Massachusetts Institute of Technology, Cambridge, MA, USA \\ ${ }^{5}$ Earth Observing Laboratory, National Center for Atmospheric Research, Boulder, CO, USA \\ ${ }^{6}$ Department of Atmospheric and Oceanic Sciences, University of California, Los Angeles, CA, USA \\ ${ }^{7}$ Atmospheric Chemistry Observations and Modeling Laboratory, National Center for Atmospheric Research, \\ Boulder, CO, USA \\ ${ }^{8}$ Rosenstiel School of Marine and Atmospheric Science, University of Miami, Miami, FL, USA \\ ${ }^{9}$ Department of Chemistry, University of California, Irvine, CA, USA \\ ${ }^{10}$ Department of Atmospheric and Oceanic Sciences, University of Colorado, Boulder, CO, USA \\ ${ }^{11}$ Department of Physics, University of Helsinki, Helsinki, Finland \\ ${ }^{a}$ now at: College of Engineering and Physical Sciences, University of New Hampshire, Durham, NH, USA
}

Correspondence to: V. Shah (vshah@uw.edu)

Received: 17 August 2015 - Published in Atmos. Chem. Phys. Discuss.: 5 October 2015

Revised: 12 January 2016 - Accepted: 15 January 2016 - Published: 10 February 2016

\begin{abstract}
We collected mercury observations as part of the Nitrogen, Oxidants, Mercury, and Aerosol Distributions, Sources, and Sinks (NOMADSS) aircraft campaign over the southeastern US between 1 June and 15 July 2013. We use the GEOS-Chem chemical transport model to interpret these observations and place new constraints on bromine radical initiated mercury oxidation chemistry in the free troposphere. We find that the model reproduces the observed mean concentration of total atmospheric mercury (THg) (observations: $1.49 \pm 0.16 \mathrm{ng} \mathrm{m}^{-3}$, model: $1.51 \pm$ $0.08 \mathrm{ng} \mathrm{m}^{-3}$ ), as well as the vertical profile of $\mathrm{THg}$. The majority $(65 \%)$ of observations of oxidized mercury $(\mathrm{Hg}(\mathrm{II}))$ were below the instrument's detection limit (detection limit per flight: $58-228 \mathrm{pg} \mathrm{m}^{-3}$ ), consistent with model-calculated $\mathrm{Hg}$ (II) concentrations of $0-196 \mathrm{pg} \mathrm{m}^{-3}$. However, for observations above the detection limit we find that modeled $\mathrm{Hg}$ (II) concentrations are a factor of 3 too low (observations: $212 \pm 112 \mathrm{pg} \mathrm{m}^{-3}$, model: $67 \pm 44 \mathrm{pg} \mathrm{m}^{-3}$ ). The high-
\end{abstract}

est $\mathrm{Hg}$ (II) concentrations, 300-680 $\mathrm{pg} \mathrm{m}^{-3}$, were observed in dry $(\mathrm{RH}<35 \%)$ and clean air masses during two flights over Texas at 5-7 km altitude and off the North Carolina coast at 1-3 km. The GEOS-Chem model, back trajectories and observed chemical tracers for these air masses indicate subsidence and transport from the upper and middle troposphere of the subtropical anticyclones, where fast oxidation of elemental mercury $(\mathrm{Hg}(0))$ to $\mathrm{Hg}(\mathrm{II})$ and lack of $\mathrm{Hg}(\mathrm{II})$ removal lead to efficient accumulation of $\mathrm{Hg}(\mathrm{II})$. We hypothesize that the most likely explanation for the model bias is a systematic underestimate of the $\mathrm{Hg}(0)+\mathrm{Br}$ reaction rate. We find that sensitivity simulations with tripled bromine radical concentrations or a faster oxidation rate constant for $\mathrm{Hg}(0)+\mathrm{Br}$, result in 1.5-2 times higher modeled $\mathrm{Hg}(\mathrm{II})$ concentrations and improved agreement with the observations. The modeled tropospheric lifetime of $\mathrm{Hg}(0)$ against oxidation to $\mathrm{Hg}$ (II) decreases from 5 months in the base simulation to $2.8-1.2$ months in our sensitivity simulations. In or- 
der to maintain the modeled global burden of $\mathrm{THg}$, we need to increase the in-cloud reduction of $\mathrm{Hg}$ (II), thus leading to faster chemical cycling between $\mathrm{Hg}(0)$ and $\mathrm{Hg}(\mathrm{II})$. Observations and model results for the NOMADSS campaign suggest that the subtropical anticyclones are significant global sources of $\mathrm{Hg}(\mathrm{II})$.

\section{Introduction}

Exposure to mercury affects the human nervous system, hinders cognitive development in children, and causes cardiovascular diseases in adults (Mergler et al., 2007; Karagas et al., 2012). In fish, mammals, and birds, mercury can adversely affect reproductive behavior (Scheuhammer et al., 2007). Although mercury is naturally present in our environment, human activities have increased its concentrations in the atmosphere and ocean by factors of 3 to 7 (Lamborg et al., 2002; Selin, 2009; Strode et al., 2010; Amos et al., 2013; Zhang et al., 2014) making mercury exposure a major public health concern.

In the troposphere, $90 \%$ of mercury occurs in its elemental form $(\operatorname{Hg}(0))$ in the gas phase, while the rest is in the oxidized (mercuric, +2$)$ state $(\mathrm{Hg}(\mathrm{II}))$, either in the gas-phase or bound to particles (Gustin et al., 2013). The chemical forms of atmospheric $\mathrm{Hg}$ (II) have not been identified, but laboratory and theoretical studies suggest that they likely include $\mathrm{HgCl}_{2}, \mathrm{HgBr}_{2}, \mathrm{HgBrBrO}, \mathrm{HgBrNO}_{2}, \mathrm{HgBrHO}_{2}, \mathrm{HgO}$, $\mathrm{HgSO}_{4}, \mathrm{Hg}\left(\mathrm{NO}_{3}\right)_{2}$, and $\mathrm{Hg}(\mathrm{OH})_{2}$ (Gustin et al., 2013; Dibble et al., 2012; Huang et al., 2015). Both natural and anthropogenic processes emit mercury to the atmosphere, mostly as $\mathrm{Hg}(0)$. Atmospheric $\mathrm{Hg}(\mathrm{II})$ originates predominantly from the oxidation of $\mathrm{Hg}(0)$, with a minor contribution from direct anthropogenic emissions (Driscoll et al., 2013). Unlike $\mathrm{Hg}(0), \mathrm{Hg}(\mathrm{II})$ is highly water-soluble and reactive, and is quickly scavenged from the atmosphere by rainwater or aerosol particles, such that $60 \%$ of the global mercury deposition is estimated to occur by wet and dry deposition of $\mathrm{Hg}$ (II) (Selin et al., 2008; Holmes et al., 2010).

Atomic bromine $(\mathrm{Br})$ has been observed as the main oxidant of atmospheric $\mathrm{Hg}(0)$ in the polar and the marine boundary layers (Lindberg et al., 2002; Ebinghaus et al., 2002; Laurier et al., 2003; Obrist et al., 2011), and laboratory studies (Ariya et al., 2002; Donohoue et al., 2006), theoretical calculations (Goodsite et al., 2004, 2012; Balabanov et al., 2005; Dibble et al., 2012; Shepler et al., 2007), and modeling studies (Holmes et al., 2006, 2010) suggest a predominant role of $\mathrm{Br}$ in the oxidation of $\mathrm{Hg}(0)$ in the global atmosphere. While other oxidants have been proposed, in particular $\mathrm{OH}$ and $\mathrm{O}_{3}$ (Hall, 1995; Spicer et al., 2002; Pal and Ariya, 2004a, b; Sumner et al., 2005; Rutter et al., 2012), theoretical studies (Calvert and Lindberg, 2005; Goodsite et al., 2004; Hynes et al., 2009) suggest that the bimolecular reaction of $\mathrm{Hg}(0)$ with $\mathrm{O}_{3}$ and $\mathrm{OH}$ is too slow in the atmosphere, and the fast rates observed in the laboratory could have been influenced by wall-mediated reactions or formation of aerosol particles (Tossell, 2006; Subir et al., 2011).

Measurements at a few high-elevation sites have shown episodic enhancements of $\mathrm{Hg}$ (II) concentrations (350$600 \mathrm{pg} \mathrm{m}^{-3}$ ) usually in low relative humidity and low $\mathrm{CO}$ air, suggesting efficient in situ production of $\mathrm{Hg}$ (II) in the free troposphere (Landis et al., 2005; Swartzendruber et al., 2006; Faïn et al., 2009; Sheu et al., 2010; Weiss-Penzias et al., 2015). Sillman et al. (2007) reported higher (60$\left.248 \mathrm{pg} \mathrm{m}^{-3}\right) \mathrm{Hg}$ (II) concentrations at $3 \mathrm{~km}$ altitude than near the surface in aircraft flights off the Florida coast. Swartzendruber et al. (2009) found a large variability in $\mathrm{Hg}$ (II) concentrations $\left(0-500 \mathrm{pg} \mathrm{m}^{-3}\right)$ during five flights over the $\mathrm{Pa}$ cific Northwest below $5 \mathrm{~km}$ altitude, with higher concentrations in free-tropospheric air with low aerosol concentrations. Lyman and Jaffe (2012) found enhanced $\mathrm{Hg}$ (II) concentrations of $\sim 450 \mathrm{pg} \mathrm{m}^{-3}$ and depleted total mercury ( $\mathrm{THg}, \mathrm{THg}=\mathrm{Hg}(0)+\mathrm{Hg}($ II $))$ concentrations $\left(<1 \mathrm{ng} \mathrm{m}^{-3}\right)$ in a stratospheric intrusion, suggesting rapid oxidation of $\mathrm{Hg}(0)$ and loss of $\mathrm{Hg}(\mathrm{II})$ above the tropopause. During multiple year-round flights over Tennessee, USA, Brooks et al. (2014) found that $\mathrm{Hg}$ (II) concentrations at $2-4 \mathrm{~km}$ altitude were $10-$ 30 times higher than those near the surface throughout the year. Typically, these past aircraft campaigns have focused on $\mathrm{Hg}$ (II) measurements over small spatial scales. The sparseness of free-tropospheric measurements of $\mathrm{Hg}$ (II) has hindered the validation of redox chemistry in global models of tropospheric mercury, which display large inter-model variability in wet and dry deposition (Bullock et al., 2008, 2009; Travnikov et al., 2010).

The Nitrogen, Oxidants, Mercury, and Aerosol Distributions, Sources, and Sinks (NOMADSS) aircraft campaign was conducted over the southeastern US to determine the distribution of $\mathrm{THg}$ and $\mathrm{Hg}(\mathrm{II})$ at a regional scale. Here, we analyze these observations using the GEOS-Chem chemical transport model with the goals of examining the origin of $\mathrm{Hg}(\mathrm{II})$ in the free troposphere and testing the kinetics of the Br-initiated oxidation mechanism.

\section{Observations and model used in this study}

\subsection{The NOMADSS campaign}

The NOMADSS aircraft campaign was conducted over the southeastern US from 1 June to 15 July 2013 using the NSF/NCAR C-130 aircraft. We conducted 19 research flights of 4-7 h duration each out of Smyrna, Tennessee $\left(36^{\circ} 1^{\prime} \mathrm{N}\right.$, $\left.86^{\circ} 31^{\prime} \mathrm{W}\right)$ (Fig. 1). NOMADSS was part of the larger Southeast Atmosphere Study (SAS), a collaborative effort to characterize the atmospheric composition over the southeastern US (http://www.eol.ucar.edu/field_projects/sas). One of the objectives of the NOMADSS campaign, and the focus of this study, was to quantify the tropospheric distribution of mercury species. Mercury measurements were made using 


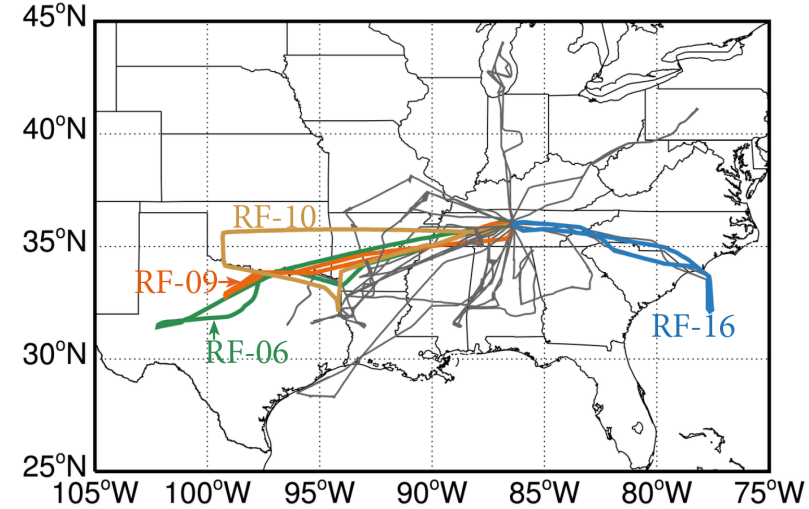

Figure 1. Flight tracks of the NSF/NCAR C-130 aircraft during the 19 NOMADSS research flights between 1 June and 15 July 2013. The flight tracks of four flights discussed in the text are highlighted (RF-06: green, RF-09: red, RF-10: brown, and RF-16: blue).

the University of Washington's Detector of Oxidized Mercury Species (UW-DOHGS), which is currently the only instrument capable of making simultaneous measurements of total and elemental mercury concentrations aboard an aircraft platform at a relatively high time resolution of $2.5 \mathrm{~min}$ (Swartzendruber et al., 2009; Lyman and Jaffe, 2012; Ambrose et al., 2013, 2015). In addition, the C-130 aircraft was equipped with other instruments summarized in Table 1.

This paper complements several other papers focused on the analysis of mercury measurements during NOMADSS. In particular, Gratz et al. (2015a) present an analysis of the high $\mathrm{Hg}$ (II) concentrations and $\mathrm{BrO}$ concentrations observed on one NOMADSS flight (research flight 6). Ambrose et al. (2015) use the NOMADSS observations to calculate enhancement ratios of $\mathrm{Hg}$ in the plumes of six coalfired power plants, and compare them to the $\mathrm{Hg}$ emission ratios reported in the emission inventories. Song et al. (2014) combine the NOMADSS observations with results from the GEOS-Chem model to constrain $\mathrm{Hg}$ emissions from land and ocean sources. Gratz et al. (2015b) use the NOMADSS observations over Lake Michigan and a plume dispersion model to quantify the outflow of $\mathrm{Hg}$ from the Chicago/Gary industrial area.

\subsection{The UW-DOHGS instrument}

The UW-DOHGS is a dual channel instrument that simultaneously measures concentrations of $\mathrm{THg}$ and $\mathrm{Hg}(0)$. Ambrose et al. (2015) discuss the configuration of the instrument during NOMADSS, in-flight calibration as well as preand post-campaign laboratory tests. Briefly, the UW-DOHGS draws a fast flow of ambient air from a rear-facing aircraft inlet heated to $110^{\circ} \mathrm{C}$ to facilitate transmission of $\mathrm{Hg}$ (II) compounds. Two Tekran ${ }^{\circledR}$ 2537B Hg vapor analyzers subsample the inlet flow at $1 \mathrm{~L} \mathrm{~min}^{-1}$ (at $0{ }^{\circ} \mathrm{C}$ and $1 \mathrm{~atm}$ ) through parallel channels. The Tekran ${ }^{\circledR}$ analyzers sample $\mathrm{Hg}(0)$ by
Au-amalgamation pre-concentration on paired sample cartridges, with quantification by cold vapor atomic fluorescence spectrometry (CVAFS). The sample integration time and measurement time resolution are both $2.5 \mathrm{~min}$. In the $\mathrm{THg}$ channel, $\mathrm{Hg}(\mathrm{II})$ compounds are reduced to $\mathrm{Hg}(0)$ by passing the sampled air through a quartz pyrolyzer heated to $650^{\circ} \mathrm{C}$. In the $\mathrm{Hg}(0)$ channel, $\mathrm{Hg}$ (II) (in gas and particlebound phases) is removed using either a quartz wool trap (first fourteen flights) or a cation exchange membrane (remaining five flights). $\mathrm{Hg}$ (II) concentrations are calculated from the difference between the $\mathrm{THg}$ and $\mathrm{Hg}(0)$ measurements. In comparison, the Tekran ${ }^{\circledR}$ 2537-1130-1135 speciation system uses $\mathrm{KCl}$ denuders to capture gas-phase oxidized mercury, which is subsequently thermally desorbed as elemental mercury for analysis (Landis et al., 2002). The measurement cycle of the Tekran ${ }^{\circledR}$ speciation system is 30 min or longer, compared to the $2.5 \mathrm{~min}$ cycle for the UW-DOHGS. The UW-DOHGS is not affected by $\mathrm{O}_{3}$-interference, unlike the Tekran ${ }^{\circledR}$ system (Lyman et al., 2010; Ambrose et al., 2013; McClure et al., 2014). A limitation of UW-DOHGS is that the quartz wool traps can release $\mathrm{Hg}$ (II) in humid conditions (Ambrose et al., 2013, 2015), which decreased the number of $\mathrm{Hg}(\mathrm{II})$ observations in the boundary layer during the first 14 flights. This was not a problem on the later five flights when cation exchange membranes were used in place of quartz wool.

During NOMADSS, the $1 \sigma$ uncertainty in $\mathrm{THg}$ and $\mathrm{Hg}(0)$ was $8-10 \%$, and the detection limit (DL) was < $0.05 \mathrm{ng} \mathrm{m}^{-3}$. For $\mathrm{Hg}(\mathrm{II})$, the $1 \sigma$ uncertainty varied between $38 \mathrm{pg} \mathrm{m}^{-3}$ (at THg of $1.2 \mathrm{ng} \mathrm{m}^{-3}$ ) and $55 \mathrm{pg} \mathrm{m}^{-3}$ (at THg of $2.8 \mathrm{ng} \mathrm{m}^{-3}$ ). The $\mathrm{Hg}(\mathrm{II}) \mathrm{DL}$ is calculated using the "same air" configuration, in which the $\mathrm{Hg}$ (II) filter is bypassed and both analyzers sample the same air downstream of the pyrolyzer in the THg channel (Ambrose et al., 2013, 2015). The $3 \sigma \mathrm{Hg}$ (II) DL for the campaign ranged between 58 and $228 \mathrm{pg} \mathrm{m}^{-3}$.

The UW-DOHGS instrument was operational during all 19 flights of the NOMADSS campaign, and concentrations of $\mathrm{THg}$ were measured continuously during each flight, except during calibration cycles. A total of 2381 (2.5 min average) observations of $\mathrm{THg}$ were made during the campaign. $\mathrm{Hg}$ (II) concentrations could be determined for only $\sim 60 \%$ of the time (1503 observations), because of periodic in-flight calibration cycles and because of reduced retention efficiency of the $\mathrm{Hg}$ (II) traps during some flight segments in the moist boundary layer. For the entire NOMADSS campaign, 35\% of the $\mathrm{Hg}(\mathrm{II})$ measurements (528 points out of 1503) were above the instrument's DL. Here and in the rest of the paper, we use ADL (Above Detection Limit) observations to refer to $\mathrm{Hg}$ (II) measurements above the instrument's DL and BDL (Below Detection Limit) for $\mathrm{Hg}$ (II) measurements below the DL. In the boundary layer (defined here as altitude $<2 \mathrm{~km}$ and water vapor $>8 \mathrm{~g} \mathrm{~kg}^{-1}$ ), $87 \%$ of the 532 observations were BDL. In the free troposphere, $53 \%$ out of the $971 \mathrm{ob}-$ servations were $\mathrm{BDL}$. 
Table 1. Chemical and meteorological measurements used in this work.

\begin{tabular}{lll}
\hline Observations & Measurement technique & Instrument model/Reference \\
\hline $\mathrm{THg}, \mathrm{Hg}(0)$, and $\mathrm{Hg}(\mathrm{II})$ & Dual-channel CVAFS (UW-DOHGS) & Lyman and Jaffe (2012); \\
& & Ambrose et al. (2013, 2015) \\
$\mathrm{BrO}$ & Differential Optical Absorption Spectroscopy & Platt and Stutz (2008) \\
$\mathrm{RH}$ & Chilled mirror hygrometry & Buck 1011C \\
$\mathrm{CO}$ & Vacuum-UV Resonance Fluorescence & Aero-Laser AL5001 \\
$\mathrm{NO}, \mathrm{NO}_{2}, \mathrm{O}_{3}$ & $\mathrm{NO}_{2}$ chemiluminescence & Ridley et al. (2004) \\
$\mathrm{CH}_{2} \mathrm{O}, \mathrm{CHBr}_{3}, \mathrm{C}_{3} \mathrm{H}_{8}$ & $\mathrm{Gas}$ chromatography/mass spectrometry & Apel et al. (2010) \\
$\mathrm{SO}_{2}$ & Pulsed fluorescence & Thermo Scientific Model 43i-TLE \\
\hline
\end{tabular}

As more than half the $\mathrm{Hg}$ (II) observations during NOMADSS were BDL, we follow the recommendation of Helsel (2011) and use the robust regression on order statistics (ROS) method to assign values for BDL observations. The ROS method assumes a lognormal distribution for the observations, and estimates the distribution's parameters using ADL measurements. The BDL values are then estimated using the fitted distribution. The ROS method is applied to calculate $\mathrm{Hg}$ (II) means and standard deviations reported in Tables 3 and 4 and Figs. 2-5.

\subsection{The GEOS-Chem model}

\subsubsection{General description}

The GEOS-Chem global 3-D atmospheric chemical transport model (www.geos-chem.org) is driven by meteorological fields from the NASA Global Modeling and Assimilation Office (GMAO) Goddard Earth Observing System (GEOS) Version 5 Forward Processing (FP). The GEOS-5 FP system consists of a general circulation model (GCM) coupled with a data assimilation (DAS) system (Rienecker et al., 2008), with a native horizontal resolution of $0.25^{\circ}$ latitude by $0.3125^{\circ}$ longitude and 72 vertical levels up to $0.01 \mathrm{hPa}$. The GEOS-5 FP meteorological fields are archived either at 1 or $3 \mathrm{~h}$ intervals, depending on the variables.

GEOS-Chem includes advection (Lin and Rood, 1996), convective transport (Wu et al., 2007), turbulent mixing (Lin and McElroy, 2010), wet deposition (Liu et al., 2001; Wang et al., 2011; Amos et al., 2012), and dry deposition (Wang et al., 1998; Zhang et al., 2011) of chemical species. The fullchemistry simulation includes an up-to-date chemical mechanism for gas-phase and heterogeneous reactions of $\mathrm{HO}_{x}$ $\mathrm{NO}_{x}$-VOC-O 3 -aerosols in the troposphere (Bey et al., 2001) with the recent addition of bromine chemistry (Parrella et al., 2012). We use here GEOS-Chem model version 9-02.

The GEOS-Chem $\mathrm{Hg}$ model simulates the emissions, chemistry, transport, and deposition of $\mathrm{Hg}(0)$ and $\mathrm{Hg}$ (II) in the atmosphere (Selin et al., 2007) with updates from Holmes et al. (2010), Amos et al. (2012), and Zhang et al. (2012), coupled with a 2-D ocean model (Strode et al., 2007; Soerensen et al., 2010) and a 2-D land model (Selin et al., 2008;
Holmes et al., 2010). The model includes prescribed emissions from biomass burning and geogenic activity (Holmes et al., 2010). The global GEOS-Chem $\mathrm{Hg}$ simulation, with a resolution of $4^{\circ}$ latitude $\times 5^{\circ}$ longitude, was evaluated by Holmes et al. (2010), who found the modeled $\mathrm{THg}$ $\left(1.71 \pm 0.5 \mathrm{ng} \mathrm{m}^{-3}\right)$ to be in good agreement with observations $\left(1.86 \pm 1.0 \mathrm{ng} \mathrm{m}^{-3}\right.$, correlation coefficient $\left.=0.9\right)$ at 39 land-based sites across the globe. Simulated THg concentrations were about $10 \%$ higher than $\mathrm{THg}$ concentrations measured during three aircraft campaigns (INTEX-B, CARIBIC, and ARCTAS), but modeled vertical profiles were consistent with observations in the troposphere. Zhang et al. (2012) developed a nested-grid $\mathrm{Hg}$ simulation in GEOS-Chem, using a higher horizontal resolution $\left(0.5^{\circ} \times 0.667^{\circ}\right)$ over North America. They found that the average annual modeled wet deposition $\left(7.2 \pm 3.2 \mu \mathrm{g} \mathrm{m}^{-2} \mathrm{yr}^{-1}\right)$ at 95 Mercury Deposition Network (MDN; http://nadp.sws.uiuc.edu/mdn/) sites was close to the observations $\left(8.8 \pm 3.6 \mu \mathrm{g} \mathrm{m}^{-2} \mathrm{yr}^{-1}\right)$ and showed a correlation coefficient of 0.78 . The modeled annual mean $\mathrm{THg}$ concentrations $\left(1.42 \pm 0.11 \mathrm{ng} \mathrm{m}^{-3}\right)$ were unbiased with respect to the observations $\left(1.46 \pm 0.11 \mathrm{ng} \mathrm{m}^{-3}\right)$ at 19 surface-based sites. While the modeled gaseous $\mathrm{Hg}$ (II) concentrations at these sites were higher than the observations by a factor of 1.5 , the model captured the observed seasonal cycle with higher concentrations during spring and summer at most sites.

\subsubsection{Updates to Hg emissions in GEOS-Chem}

We have updated the global anthropogenic $\mathrm{Hg}$ emissions to the United Nations Environment Programme (UNEP)/Arctic Monitoring and Assessment Program (AMAP) 2010 (http:// www.amap.no/mercury-emissions/datasets), and over North America we use the U.S. EPA National Emissions Inventory (NEI) 2011 (http://www.epa.gov/ttnchie1/net/2011inventory. html) and Environment Canada's National Pollutant Release Inventory (NPRI) 2011 emission inventories. The speciation of anthropogenic emissions is assumed to be $90 \%$ $\mathrm{Hg}(0): 10 \% \mathrm{Hg}$ (II) from all anthropogenic sources based on Zhang et al. (2012) and Kos et al. (2013). For 2013, the GEOS-Chem global emission of mercury is $1850 \mathrm{Mg} \mathrm{a}^{-1}$ from anthropogenic sources, $5025 \mathrm{Mga}^{-1}$ from natural 
sources and re-emission, and $225 \mathrm{Mga}^{-1}$ from biomass burning. For 1 June-15 July 2013, the anthropogenic, natural, and biomass burning emissions over North America are 130,870 , and $22 \mathrm{~kg} \mathrm{~d}^{-1}$, respectively.

\subsubsection{Updates to Hg chemistry in GEOS-Chem}

The oxidation of $\operatorname{Hg}(0)$ is modeled as a two-step reaction initiated by $\mathrm{Br}$ radicals as originally implemented in GEOSChem by Holmes et al. (2010), based on the work of Goodsite et al. (2004); Donohoue et al. (2006), and Balabanov et al. (2005):

$$
\begin{aligned}
& \mathrm{Hg}(0)+\mathrm{Br} \stackrel{\mathrm{M}}{\longrightarrow} \mathrm{HgBr} \\
& \mathrm{HgBr}+\mathrm{M} \rightarrow \mathrm{Hg}(0)+\mathrm{Br}+\mathrm{M} \\
& \mathrm{HgBr}+\mathrm{Br} \rightarrow \mathrm{Hg}(0)+\mathrm{Br}_{2} \\
& \mathrm{HgBr}+X \rightarrow \mathrm{Hg}(\mathrm{II}) \quad\left(X=\mathrm{OH}, \mathrm{Br}, \mathrm{HO}_{2}, \mathrm{NO}_{2}, \mathrm{BrO}\right)
\end{aligned}
$$

We use the recently corrected rate constant for the $\mathrm{HgBr}$ dissociation Reaction (R2) (Goodsite et al., 2012). Holmes et al. (2010) had assumed $\mathrm{Br}$ and $\mathrm{OH}$ as the second-step oxidants (Reaction R4). In addition, based on the recommendations of Dibble et al. (2012), we have updated this mechanism to include $\mathrm{HO}_{2}, \mathrm{NO}_{2}$, and $\mathrm{BrO}$ as the second-step oxidants. The rates constants used here are

$$
\begin{aligned}
k_{1}= & 1.46 \times 10^{-32} \times\left(\frac{T}{298}\right)^{-1.86} \\
\times & {[\mathrm{M}] \mathrm{cm}^{-3} \text { molecule } \mathrm{s}^{-1} \mathrm{~s}^{-1} } \\
& (\text { Donohoue et al., 2006) }
\end{aligned}
$$

$k_{2}=2.67 \times 10^{41} \exp \left(\frac{-7292}{T}\right)\left(\frac{T}{298}\right)^{1.76} \times k_{1} \mathrm{~s}^{-1}$

(Goodsite et al., 2012)

$k_{3}=3.9 \times 10^{-11} \mathrm{~cm}^{-3}$ molecule $\mathrm{e}^{-1} \mathrm{~s}^{-1}$

(Balabanov et al., 2005)

$k_{4}=2.5 \times 10^{-10} \times\left(\frac{T}{298}\right)^{-0.57} \mathrm{~cm}^{-3}$ molecule $\mathrm{s}^{-1}$

(Goodsite et al., 2012; Dibble et al., 2012)

The reduction of $\mathrm{Hg}(\mathrm{II})$ to $\mathrm{Hg}(0)$ is assumed to occur in cloud droplets in the presence of sunlight. The reduction is assumed to be proportional to the photolysis frequency of $\mathrm{NO}_{2}$, and the coefficient is estimated by constraining the model results with the observed mean burden of THg in the troposphere (Holmes et al., 2010). The uptake of $\mathrm{Hg}$ (II) by sea-salt particles is simulated as a kinetic mass transfer process (Holmes et al., 2010). For non sea-salt aerosol particles, gas-particle partitioning is simulated as an equilibrium process based on an empirical relationship (Amos et al., 2012). The modeled wet and dry deposition of gas-phase $\mathrm{Hg}$ (II) is analogous to that of $\mathrm{HNO}_{3}$, and of particle-bound $\mathrm{Hg}$ (II) to that of sulfate particles.

\subsubsection{Simulations conducted for this study}

In this study, the GEOS-Chem $\mathrm{Hg}$ model is run in a one-way nested-grid configuration, with the native horizontal resolution $\left(0.25^{\circ} \times 0.3125^{\circ}\right)$ over North America, and a coarser resolution $\left(2^{\circ} \times 2.5^{\circ}\right)$ globally. Both the coarse- and finegrid models share the same vertical resolution with 47 layers (13 layers in the bottom $2 \mathrm{~km}$, and 16 layers between 2 and $10 \mathrm{~km}$ ). The global Hg model is spun-up with a 3-year simulation, and is then used to generate the initial and boundary conditions for the nested-domain, and to calculate the annual global mercury budget. Monthly concentrations of $\mathrm{Br}$, $\mathrm{BrO}, \mathrm{OH}, \mathrm{HO}_{2}, \mathrm{NO}_{2}, \mathrm{O}_{3}$, and aerosols are obtained from a 1-year $4^{\circ} \times 5^{\circ}$ global $\mathrm{HO}_{x}-\mathrm{NO}_{x}-\mathrm{VOC}-\mathrm{O}_{3}-\mathrm{BrO}_{x}$-aerosols tropospheric chemistry GEOS-Chem simulation. We run the nested $0.25^{\circ} \times 0.3125^{\circ} \mathrm{Hg}$ model for North America from 1 June to 15 July 2013. For comparison to the NOMADSS aircraft observations, the model is sampled along the flight track at the $2.5 \mathrm{~min}$ time step of the UW-DOHGS instrument.

In addition to the BASE simulation with the $\mathrm{Hg}(0)+\mathrm{Br}$ chemistry described above (Sect. 2.3.3), we perform five sensitivity simulations (Table 2), and focus on two of them. In the first sensitivity simulation $(3 \times \mathrm{Br})$ we increase the GEOS-Chem $\mathrm{Br}$ and $\mathrm{BrO}$ concentrations by a factor of 3 in the $45^{\circ} \mathrm{S}$ to $45^{\circ} \mathrm{N}$ latitude band between $750 \mathrm{hPa}$ and the tropopause. Parrella et al. (2012) found that the GEOSChem $\mathrm{BrO}$ is within the $\mathrm{BrO}$ measurement uncertainties of the GOME-2 satellite in the polar regions and at midlatitudes, but in the tropics the GEOS-Chem $\mathrm{BrO}$ is too low by a factor of 2-4 throughout the year (Fig. 5 of Parrella et al., 2012). Furthermore, recent aircraft-based observations of $\mathrm{BrO}$ in the tropical and subtropical free troposphere of the Southern Hemisphere reported concentrations which were 2-4 times higher than predicted by the GEOS-Chem model (Wang et al., 2015).

In the second sensitivity simulation (FastK), we replace the Donohoue et al. (2006) rate constant for Reaction (R1) by the faster rate constant measured by Ariya et al. (2002). Following Dibble et al. (2012), we proportionally increase the rate constant for the backward Reaction (R2) as follows:

$$
\begin{aligned}
k_{1, \text { FastK }}= & 3.6 \times 10^{-12} \\
\times & \left(\frac{[\mathrm{M}]_{T, p}}{[\mathrm{M}]_{273.15 \mathrm{~K}, 1 \mathrm{~atm}}}\right) \mathrm{cm}^{-3} \text { molecule }^{-1} \mathrm{~s}^{-1} \\
& \text { (Ariya et al., 2002) } \\
k_{2, \text { FastK }=} & k_{2} \times\left(\frac{k_{1, \text { FastK }}}{k_{1}}\right) \mathrm{s}^{-1}
\end{aligned}
$$

(Goodsite et al., 2012, Dibble et al., 2012).

Relative to the BASE simulation, $k_{1 \text {,FastK }}$ and $k_{2 \text {,FastK }}$ are 10 times larger near the surface and 5 times larger in the upper troposphere $(10-12 \mathrm{~km})$. For both these sensitivity simulations, the in-cloud reduction rate is increased such that the tropospheric burden and lifetime of $\mathrm{THg}$ is similar to the 
Table 2. Summary of GEOS-Chem simulations performed for this study.

\begin{tabular}{|c|c|c|}
\hline Simulation & Oxidants & Reaction rate constants $\left(\mathrm{cm}^{3}\right.$ molecule $\left.{ }^{-1} \mathrm{~s}^{-1}\right)$ \\
\hline \multicolumn{3}{|c|}{ Main simulations } \\
\hline BASE & $\begin{array}{l}\mathrm{Br} \text { (Concentrations from the GEOS-Chem } \\
\text { full-chemistry simulation) }\end{array}$ & $\begin{array}{l}\mathrm{Hg}(0)+\mathrm{Br}: k=1.46 \times 10^{-32} \times\left(\frac{T}{298}\right)^{-1.86} \times[\mathrm{M}] \\
\text { (Donohoue et al., 2006) }\end{array}$ \\
\hline $3 \times \mathrm{Br}$ & $\begin{array}{l}\mathrm{Br} \text { (Concentrations scaled by a factor of } 3 \\
\text { in the region bounded by } 45^{\circ} \mathrm{S} \text { and } 45^{\circ} \mathrm{N}, \\
\text { and } 750 \mathrm{hPa} \text { and the tropopause.) }\end{array}$ & Same as BASE \\
\hline FastK & Same as BASE & $\begin{array}{l}\mathrm{Hg}(0)+\mathrm{Br}: k=3.6 \times 10^{-12} \times\left(\frac{\mathrm{M}_{T, p}}{\mathrm{M}_{273.15 \mathrm{~K}, 1 \mathrm{~atm}}}\right) \\
\text { (Ariya et al., 2002) }\end{array}$ \\
\hline
\end{tabular}

Supplemental simulations

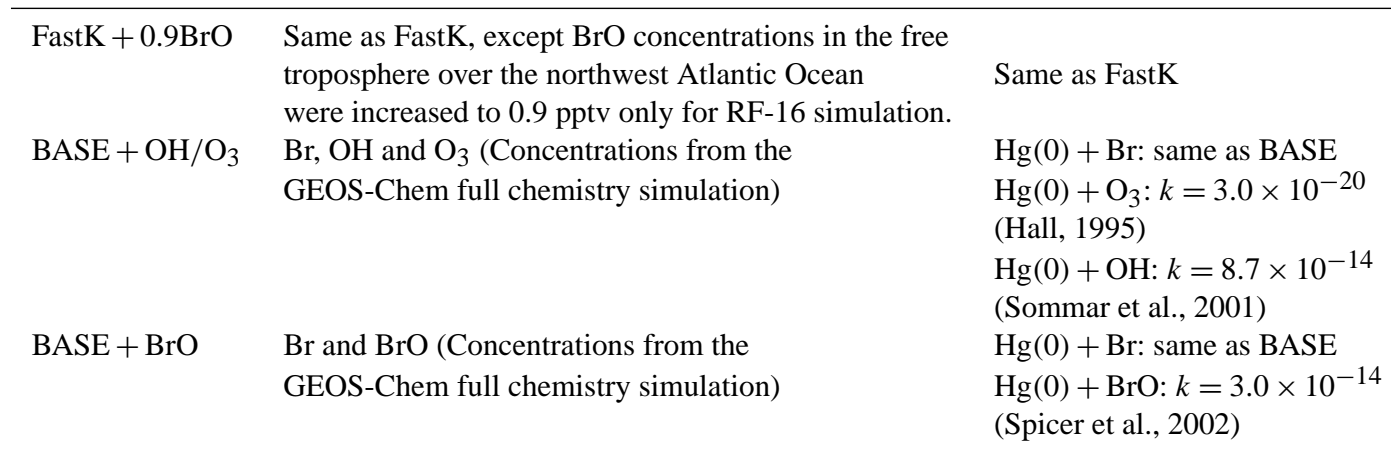

BASE simulation. This enables us to isolate the model's sensitivity to the redox chemistry of $\mathrm{Hg}$.

At the 39 global land-based sites considered previously by Holmes et al. (2010), the results of the BASE $\left(1.71 \mathrm{ng} \mathrm{m}^{-3}\right)$, $3 \times \mathrm{Br}\left(1.74 \mathrm{ng} \mathrm{m}^{-3}\right)$, and FastK $\left(1.64 \mathrm{ng} \mathrm{m}^{-3}\right)$ models are comparable to the observations $\left(1.86 \mathrm{ng} \mathrm{m}^{-3}\right)$. Figure $\mathrm{S} 1$ (in the Supplement) shows a comparison with observations of the inter-hemispheric gradient and the seasonal cycle of total gaseous $\mathrm{Hg}$ concentrations.

\section{Observed horizontal and vertical distribution of $\mathrm{THg}$ and $\mathrm{Hg}(\mathrm{II})$}

The vertical and horizontal distributions of $\mathrm{THg}$ and $\mathrm{Hg}$ (II) concentrations observed during NOMADSS are presented in Figs. 2 and 3. We exclude from these figures and the rest of our analysis fresh pollution plumes, where $\mathrm{NO}_{x}$, $\mathrm{SO}_{2}$, or $\mathrm{C}_{3} \mathrm{H}_{8}$ exceed 2 ppbv. This eliminates $6 \%$ of the $\mathrm{THg}$ and $4 \%$ of the $\mathrm{Hg}$ (II) measurements. The mean and standard deviation of the observed $\mathrm{THg}$ concentrations was $1.49 \pm 0.16 \mathrm{ng} \mathrm{m}^{-3}$ (Fig. 3a). THg concentrations decrease slightly with altitude, from $1.54 \mathrm{ng} \mathrm{m}^{-3}$ near the surface to $1.38 \mathrm{ng} \mathrm{m}^{-3}$ at $6-7 \mathrm{~km}$ altitude (Fig. 2a), which is in agreement with previous aircraft-based measurements of THg over North America (Talbot et al., 2007; Swartzendruber et al., 2009; Mao et al., 2010). The variability in $\mathrm{THg}$ concentration is small, with standard deviations at different levels ranging from 6 to $15 \%$ of the mean concentrations. The weak vertical gradient and the low standard deviation of the THg concentrations are consistent with the long tropospheric lifetime of THg.

For $\mathrm{Hg}(\mathrm{II})$, the observed mean concentration was $212 \pm$ $112 \mathrm{pg} \mathrm{m}^{-3}$, for ADL measurements (35\% of measurements) (Table 3 ). When we include BDL values using the ROS method (see Sect. 2.2), the mean $\mathrm{Hg}$ (II) concentration is $110 \pm 103 \mathrm{pg} \mathrm{m}^{-3}$ (Table 3). In order to assess the overall mean distribution of $\mathrm{Hg}(\mathrm{II})$ during NOMADSS, Figs. $2 \mathrm{~b}$ and $3 c$ display the $\mathrm{Hg}$ (II) statistics that include BDL values estimated with the ROS method. Figure $2 b$ shows that observed $\mathrm{Hg}$ (II) concentrations increased from $40 \mathrm{pg} \mathrm{m}^{-3}$ at $0-1 \mathrm{~km}$ altitude to $200 \mathrm{pg} \mathrm{m}^{-3}$ at $6-7 \mathrm{~km}$ (Fig. 2b). Large enhancements in $\mathrm{Hg}$ (II) concentrations, of up to $500 \mathrm{pg} \mathrm{m}^{-3}$, were observed at 5-7 km during two research flights (RF) over Texas (RF-06 and RF-09, box 1 in Figs. 2b and 3d). Concentrations of up to $680 \mathrm{pg} \mathrm{m}^{-3}$ were observed at $1-3 \mathrm{~km}$ on one flight over the Atlantic Ocean (RF-16). We will discuss these flights in more detail in Sect. 6. Table S1 in the Supplement presents a summary of $\mathrm{Hg}$ (II) observations on all flights.

Previous $\mathrm{Hg}$ (II) measurements at high-elevation ground sites and from aircraft showed that high free tropospheric $\mathrm{Hg}$ (II) concentrations were generally observed in air masses that were dry and clean (Landis et al., 2005; Swartzendruber et al., 2006, 2009; Faïn et al., 2009; Sheu et al., 2010). To examine whether this relation holds for the NOMADSS observations, we classify all $\mathrm{THg}$ and $\mathrm{Hg}$ (II) observations 
Table 3. Chemical characteristics of NOMADSS observations classified in four air mass categories.

\begin{tabular}{|c|c|c|c|c|c|}
\hline & All observations & low RH/low CO & low RH/high $\mathrm{CO}$ & high $\mathrm{RH} /$ low $\mathrm{CO}$ & high $\mathrm{RH} /$ high $\mathrm{CO}$ \\
\hline No of THg observations ${ }^{\mathrm{a}}$ & 2381 & 233 & 551 & 212 & 1385 \\
\hline THg observations $\left(\mathrm{ng} \mathrm{m}^{-3}\right)$ & $1.49 \pm 0.16$ & $1.35 \pm 0.15$ & $1.48 \pm 0.11$ & $1.44 \pm 0.20$ & $1.53 \pm 0.15$ \\
\hline No of $\mathrm{Hg}(\mathrm{II})$ observations ${ }^{\mathrm{b}}$ & 1503 & 184 & 414 & 159 & 746 \\
\hline (ADL) & $(528)$ & $(132)$ & (244) & (47) & $(105)$ \\
\hline $\mathrm{Hg}(\mathrm{II})$ all observations $\left(\mathrm{pg} \mathrm{m}^{-3}\right)^{\mathrm{c}}$ & $110 \pm 103$ & $239 \pm 141$ & $146 \pm 81$ & $108 \pm 123$ & $48 \pm 57$ \\
\hline$(A D L)^{d}$ & $(212 \pm 112)$ & $(289 \pm 136)$ & $(189 \pm 76)$ & $(249 \pm 140)$ & $(155 \pm 73)$ \\
\hline Altitude (km) & $2.6 \pm 1.9$ & $4.6 \pm 1.8$ & $3.9 \pm 1.2$ & $2.9 \pm 2.2$ & $1.7 \pm 1.5$ \\
\hline $\mathrm{RH}(\%)$ & $49 \pm 27$ & $16 \pm 10$ & $15 \pm 9$ & $68 \pm 17$ & $66 \pm 13$ \\
\hline $\mathrm{CO}$ (ppbv) & $107 \pm 33$ & $65 \pm 4$ & $97 \pm 13$ & $65 \pm 3$ & $124 \pm 30$ \\
\hline $\mathrm{O}_{3}$ (ppbv) & $55 \pm 14$ & $52 \pm 16$ & $63 \pm 17$ & $43 \pm 16$ & $54 \pm 10$ \\
\hline $\mathrm{NO}_{x}(\mathrm{pptv})$ & $158 \pm 156$ & $55 \pm 32$ & $67 \pm 34$ & $44 \pm 39$ & $232 \pm 170$ \\
\hline $\mathrm{CH}_{2} \mathrm{O}(\mathrm{ppbv})$ & $1.8 \pm 1.4$ & $0.5 \pm 0.3$ & $0.7 \pm 0.3$ & $0.9 \pm 0.4$ & $2.7 \pm 1.3$ \\
\hline
\end{tabular}

The four air mass categories are based on thresholds of $\mathrm{RH}=35 \%$ and $\mathrm{CO}=75 \mathrm{ppbv}$. The mean and standard deviation for each category are indicated. ${ }^{\mathrm{a}} \mathrm{Number}$ of $2.5 \mathrm{~min} \mathrm{THg}$ samples. ${ }^{\mathrm{b}}$ Total number of $2.5 \mathrm{~min} \mathrm{Hg}$ (II) samples, including samples below the detection limit (BDL). The number in parenthesis indicates the number of 2.5 min $\mathrm{Hg}$ (II) samples above the detection limit (ADL). ${ }^{\mathrm{c}}$ Mean $\mathrm{Hg}$ (II) concentration and standard deviation for all observations, including BDL as estimated using the ROS method. ${ }^{\mathrm{d}} \mathrm{Mean} \mathrm{Hg}(\mathrm{II})$ concentration and standard deviation for ADL observations.

(a) -r Observations = BASE Model

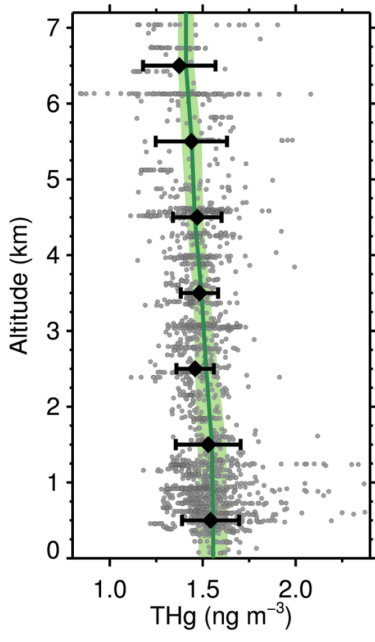

(b)

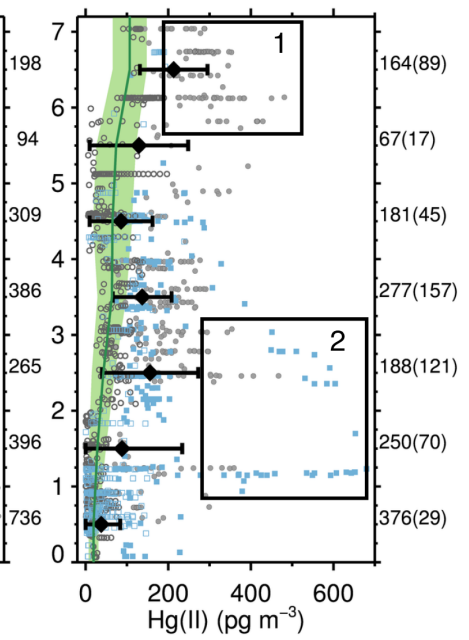

Figure 2. Vertical profiles of (a) $\mathrm{THg}$ and (b) $\mathrm{Hg}$ (II) during NOMADSS. Individual $2.5 \mathrm{~min}$ observations are shown with grey circles (for $\mathrm{THg}$ and $\mathrm{Hg}$ (II) measured using the quartz wool filter) and blue squares (for $\mathrm{Hg}$ (II) measured using the cation exchange membrane filter). Observations above the detection limit (ADL) are indicated as filled circles/squares, while observations below the detection limit (BDL) are shown as open circles/squares and are estimated using the regression on order statistics (ROS) method. The means and standard deviations calculated for $1 \mathrm{~km}$ vertical bins are shown for the observations (black diamonds and error bars) and the BASE GEOS-Chem simulation (green line and shading). The numbers on the right hand side of each panel indicate the number of $2.5 \mathrm{~min}$ observations in each $1 \mathrm{~km}$ bin. For $\mathrm{Hg}$ (II), the second number in parenthesis indicates the number of ADL observations. The areas marked as "1" and "2" highlight measurements of high $\mathrm{Hg}$ (II) concentrations and are referenced in the text and Fig. 3. based on the measured relative humidity $(\mathrm{RH})$ and $\mathrm{CO}$ concentrations (Table 3). We use thresholds of $\mathrm{RH}=35 \%$ and $\mathrm{CO}=75 \mathrm{ppbv}$ to classify the observations into four categories: "high RH/high CO", "high RH/low CO", "low $\mathrm{RH} /$ high CO”, and "low RH/low CO”. When RH or CO measurements were not available (18\% of the observations), we use the GEOS-Chem simulated RH values and CO concentrations. The ROS procedure is used to assign values for BDL observations separately for each category.

Using this method, $\mathrm{Hg}(\mathrm{II})$ observations partition into the four categories as follows (Table 3): "low RH/low CO" (12\% of observations), "low RH/high CO" (28\%), "high RH/low CO" (10\%), "high RH/high CO" (50\%). The highest mean concentrations of $\mathrm{Hg}$ (II) are found in the "low RH/low CO" category (239 $\mathrm{pg} \mathrm{m}^{-3}$ for all observations, $289 \mathrm{pg} \mathrm{m}^{-3}$ for ADL observations). Observations in this category had the lowest average $\mathrm{THg}$ concentrations $\left(1.35 \mathrm{ng} \mathrm{m}^{-3}\right)$, and were relatively clean with low mixing ratios for $\mathrm{CH}_{2} \mathrm{O}(0.5 \mathrm{ppbv})$, $\mathrm{NO}_{x}$ (55 pptv), $\mathrm{O}_{3}$ (52 ppbv), and a mean $\mathrm{RH}$ of $16 \%$. These air samples were observed mainly during the high-altitude (5-7 km) flights over Texas (RF-06 and RF-09), and at 1$3 \mathrm{~km}$ over the Atlantic on RF-16. The chemical characteristics and HYbrid Single-Particle Lagrangian Integrated Trajectory (HYSPLIT) (Draxler and Hess, 1998) back trajectories for these "low RH/low CO" air masses indicate subsidence from the clean subtropical upper troposphere (Sect. 6).

The "low RH/high CO" category displays moderate enhancements in $\mathrm{Hg}(\mathrm{II})$ concentrations, with a mean of $146 \mathrm{pg} \mathrm{m}^{-3}$ (189 $\mathrm{pg} \mathrm{m}^{-3}$ for ADL observations). Back trajectories (not shown here) indicate transport from high latitudes $\left(>60^{\circ} \mathrm{N}\right)$ accompanied by subsidence. The mean concentrations of $\mathrm{NO}_{x}(67 \mathrm{pptv})$ and $\mathrm{CH}_{2} \mathrm{O}(0.7 \mathrm{ppbv})$ were low and similar to values for the "low RH/low CO" category, indicating relatively clean air masses but originating from the 

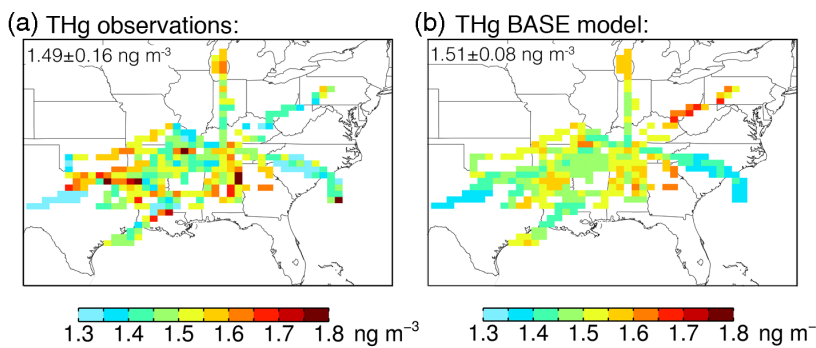

(c) $\mathrm{Hg}(\mathrm{II})$ observations

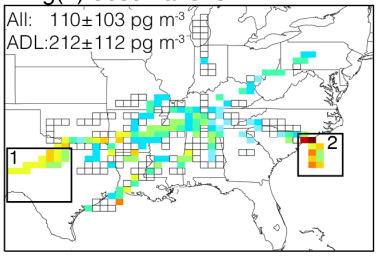

$\mathrm{BDL} 100200300400500 \mathrm{pg} \mathrm{m}^{-3}$

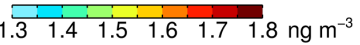
(d) $\mathrm{Hg}($ II) BASE model:

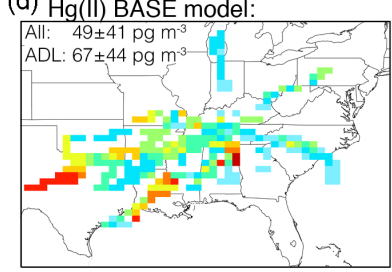

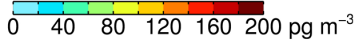

Figure 3. Horizontal distribution of $\mathrm{THg}$ (top panels) and $\mathrm{Hg}$ (II) (bottom panels). Observations are shown on panels (a, c), while results from the BASE GEOS-Chem simulation are on panels $(\mathbf{b}, \mathbf{d})$. Observed and simulated values are averaged in $0.5^{\circ}$ latitude by $0.625^{\circ}$ longitude columns. For $\mathrm{Hg}$ (II) observations, the means include ROS estimates for values below the detection limit (BDL). Locations where all observed $\mathrm{Hg}$ (II) concentrations were BDL are shown by open squares. Note the different color scales for the observed and modeled $\mathrm{Hg}(\mathrm{II})$ concentrations (c, d). Regions marked as " 1 " and " 2 " highlight the areas with high $\mathrm{Hg}$ (II) and are referenced in the text and in Fig. 2. The numbers at the top of each panel indicate the means and standard deviations for all the modeled and observed concentrations. For $\mathrm{Hg}$ (II) we separate the statistics for all the measurements ("All") and for the measurements above the detection limit ("ADL”).

mid- and upper-troposphere at high latitudes instead of tropical latitudes as in the "low RH/low CO" category.

Most of the remaining $\mathrm{Hg}$ (II) observations $(50 \%$ of observations) fall in the "high RH/high CO" category. These observations were collected mainly in the continental boundary layer, with moderately high concentrations of $\mathrm{CO}$ (124 ppbv), $\mathrm{CH}_{2} \mathrm{O}$ (2.7 ppbv), and $\mathrm{NO}_{x}$ (232 pptv). In this category, the mean concentration of $\mathrm{THg}$ is $1.53 \mathrm{ng} \mathrm{m}^{-3}$, while that of $\mathrm{Hg}$ (II) is $48 \mathrm{pg} \mathrm{m}^{-3}$ ( $155 \mathrm{pg} \mathrm{m}^{-3}$ for ADL observations, which account for only $14 \%$ of observations in this category). The "high RH/low CO" category has lower $\mathrm{CO}$ (68 ppbv), $\mathrm{CH}_{2} \mathrm{O}$ (0.9 ppbv), $\mathrm{NO}_{x}$ (44 pptv), and $\mathrm{O}_{3}$ (43 ppbv). These samples were observed mostly near the marine boundary layer over the Atlantic Ocean (RF-14 and RF16), but some were observed at high altitudes possibly in air detrained from clouds. In this category, the mean concentration of THg is $1.44 \mathrm{ng} \mathrm{m}^{-3}$, and that of $\mathrm{Hg}$ (II) is $108 \mathrm{pg} \mathrm{m}^{-3}$ ( $249 \mathrm{pg} \mathrm{m}^{-3}$ for ADL observations, $30 \%$ of the observations).

The observations of $\mathrm{Hg}(\mathrm{II})$ during NOMADSS are similar to previous observations of $\mathrm{Hg}$ (II) in terms of their magnitude, vertical profiles, and airmass characteristics. During

five summertime flights in the Pacific Northwest, Swartzendruber et al. (2009) also found RGM (gaseous component of $\mathrm{Hg}(\mathrm{II}))$ to be generally below the instrument's DL of $80-160 \mathrm{pg} \mathrm{m}^{-3}$. They found high RGM air masses (200$500 \mathrm{pg} \mathrm{m}^{-3}$ ) on two flights at $2-6 \mathrm{~km}$ altitude. These air masses had low aerosol extinction coefficient, indicating either larger production of RGM at higher altitudes or loss of RGM in the presence of aerosol particles (Swartzendruber et al., 2009). On 28 flights from August 2012 to June 2013, Brooks et al. (2014) found that mean RGM and PBM (particle-bound component of $\mathrm{Hg}(\mathrm{II})$ ) concentrations at $0-6 \mathrm{~km}$ over Tennessee, USA were 34 and $30 \mathrm{pg} \mathrm{m}^{-3}$, respectively. Highest concentrations on each flight were always observed at $2-4.5 \mathrm{~km}$ altitude. RGM concentrations exhibited a minimum in the winter months and a maximum in the summer months. On one flight in June 2013, the vertical profile of RGM showed a steep increase from the surface $\left(\sim 5 \mathrm{pg} \mathrm{m}^{-3}\right)$ to $4 \mathrm{~km}$ altitude $\left(120 \mathrm{pg} \mathrm{m}^{-3}\right)$ fol-

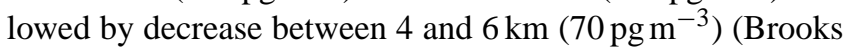
et al., 2014). At the high elevation Mt. Bachelor Observatory (2.7 kma.s.1.) in Oregon, the mean RGM concentration during May-August 2005 was $43 \mathrm{pg} \mathrm{m}^{-3}$ (Swartzendruber et al., 2006). Low RGM concentrations $\left(<50 \mathrm{pg} \mathrm{m}^{-3}\right)$ were seen in boundary layer air during the day, and higher concentrations were seen in free-tropospheric air during the night. The highest $10 \%$ of nighttime RGM concentrations were between 160 and $600 \mathrm{pg} \mathrm{m}^{-3}$, and were measured in air with low RH and low $\mathrm{CO}$, in similarity to the observations of high $\mathrm{Hg}(\mathrm{II})$ in our "low RH/low CO" category during NOMADSS.

\section{Comparison to the BASE GEOS-Chem Hg simulation}

THg concentrations simulated in the BASE GEOS-Chem model $\left(1.51 \pm 0.08 \mathrm{ng} \mathrm{m}^{-3}\right)$ agree well with observations $\left(1.49 \pm 0.16 \mathrm{ng} \mathrm{m}^{-3}\right)$ (Fig. 3a, b). The model captures the lower THg concentrations observed over central Texas, South Carolina, and part of the Atlantic Ocean, but overestimates $\mathrm{THg}$ concentrations over the Ohio River Valley by $\sim 20 \%$, possibly because of recent reductions in power plant emissions of mercury not captured in the 2011 NEI inventory used in our study. The model reproduces the vertical profile of observed THg, decreasing from $1.57 \mathrm{ng} \mathrm{m}^{-3}$ (observed: $1.54 \pm 0.15 \mathrm{ng} \mathrm{m}^{-3}$ ) near the surface to $1.43 \mathrm{ng} \mathrm{m}^{-3}$ (observed: $1.38 \pm 0.19 \mathrm{ng} \mathrm{m}^{-3}$ ) at 6-7 $\mathrm{km}$ altitude. However, we note that the variability of modeled THg in each $1 \mathrm{~km}$ bin (shaded green area in Fig. 2a) is a factor of 2 to 5 lower than the observed variability. Overall, the GEOS-Chem THg concentrations are within $\pm 10 \%$ of the measured concentrations for $70 \%$ of the observations, which indicates that the model provides reasonable simulations of the emissions and mean lifetime of THg in the lower and middle troposphere during NOMADSS. 
Table 4. Modeled $\mathrm{THg}$ and $\mathrm{Hg}(\mathrm{II})$ concentrations in the three GEOS-Chem Hg simulations for the four air mass categories.

\begin{tabular}{|c|c|c|c|c|c|}
\hline & All observations & "low RH/low CO" & "low RH/high CO" & "high RH/low CO" & "high RH/high CO" \\
\hline \multicolumn{6}{|c|}{ Observed $\mathrm{Hg}(\mathrm{II})\left(\mathrm{pg} \mathrm{m}^{-3}\right)$} \\
\hline All & $110 \pm 103$ & $239 \pm 141$ & $146 \pm 81$ & $108 \pm 123$ & $48 \pm 57$ \\
\hline (ADL) & $212 \pm 112$ & $289 \pm 136$ & $189 \pm 76$ & $249 \pm 140$ & $155 \pm 73$ \\
\hline \multicolumn{6}{|c|}{ BASE model $\mathrm{Hg}(\mathrm{II})\left(\mathrm{pg} \mathrm{m}^{-3}\right)$} \\
\hline All & $49 \pm 41$ & $99 \pm 48$ & $76 \pm 36$ & $20 \pm 25$ & $28 \pm 19$ \\
\hline$(\mathrm{ADL})^{\mathrm{a}}$ & $67 \pm 44$ & $96 \pm 51$ & $75 \pm 34$ & $14 \pm 18$ & $38 \pm 19$ \\
\hline$(\mathrm{BDL})^{\mathrm{b}}$ & $39 \pm 44$ & $105 \pm 37$ & $78 \pm 39$ & $22 \pm 27$ & $26 \pm 18$ \\
\hline \multicolumn{6}{|c|}{$3 \times \mathrm{Br}$ model $\mathrm{Hg}(\mathrm{II})\left(\mathrm{pg} \mathrm{m}^{-3}\right)$} \\
\hline All & $62 \pm 72$ & $162 \pm 104$ & $91 \pm 67$ & $28 \pm 41$ & $29 \pm 28$ \\
\hline$(\mathrm{ADL})^{\mathrm{a}}$ & $98 \pm 94$ & $176 \pm 116$ & $94 \pm 76$ & $19 \pm 30$ & $44 \pm 29$ \\
\hline$(\mathrm{BDL})^{\mathrm{b}}$ & $43 \pm 94$ & $124 \pm 47$ & $86 \pm 51$ & $31 \pm 45$ & $26 \pm 27$ \\
\hline \multicolumn{6}{|c|}{ FastK model $\mathrm{Hg}(\mathrm{II})\left(\mathrm{pg} \mathrm{m}^{-3}\right)$} \\
\hline All & $80 \pm 98$ & $208 \pm 144$ & $128 \pm 95$ & $18 \pm 25$ & $34 \pm 32$ \\
\hline$(\mathrm{ADL})^{\mathrm{a}}$ & $125 \pm 120$ & $216 \pm 160$ & $128 \pm 89$ & $16 \pm 17$ & $55 \pm 42$ \\
\hline$(\mathrm{BDL})^{\mathrm{b}}$ & $55 \pm 120$ & $189 \pm 88$ & $129 \pm 102$ & $19 \pm 28$ & $31 \pm 28$ \\
\hline \multicolumn{6}{|c|}{ Observed THg $\left(\mathrm{ng} \mathrm{m}^{-3}\right)$} \\
\hline All & $1.49 \pm 0.16$ & $1.35 \pm 0.15$ & $1.48 \pm 0.11$ & $1.44 \pm 0.20$ & $1.53 \pm 0.15$ \\
\hline \multicolumn{6}{|c|}{ BASE model THg $\left(\mathrm{ng} \mathrm{m}^{-3}\right)$} \\
\hline All & $1.51 \pm 0.08$ & $1.43 \pm 0.06$ & $1.50 \pm 0.05$ & $1.40 \pm 0.03$ & $1.55 \pm 0.07$ \\
\hline \multicolumn{6}{|c|}{$3 \times \mathrm{Br}$ model $\mathrm{THg}\left(\mathrm{ng} \mathrm{m}^{-3}\right)$} \\
\hline All & $1.51 \pm 0.11$ & $1.40 \pm 0.09$ & $1.50 \pm 0.08$ & $1.36 \pm 0.04$ & $1.55 \pm 0.10$ \\
\hline \multicolumn{6}{|c|}{ FastK model THg $\left(\mathrm{ng} \mathrm{m}^{-3}\right)$} \\
\hline All & $1.52 \pm 0.09$ & $1.44 \pm 0.07$ & $1.52 \pm 0.06$ & $1.40 \pm 0.04$ & $1.55 \pm 0.08$ \\
\hline
\end{tabular}

${ }^{a}$ Model values corresponding to ADL observations. ${ }^{b}$ Model values corresponding to BDL observations.

Because the majority of $\mathrm{Hg}(\mathrm{II})$ measurements are below the $58-228 \mathrm{pg} \mathrm{m}^{-3}$ DL of the UW-DOHGS instrument, we consider ADL and BDL observations separately. Table 4 shows that when observed $\mathrm{Hg}(\mathrm{II})$ are BDL (65\% of measurements), the mean $\mathrm{Hg}$ (II) concentrations predicted with the BASE simulation $\left(39 \pm 34 \mathrm{pg} \mathrm{m}^{-3}\right)$ are indeed below the instrument's DL. For ADL observations, the BASE model underestimates observations by a factor of 3 (model: $67 \pm$ $44 \mathrm{pg} \mathrm{m}^{-3}$, observations: $212 \pm 112 \mathrm{pg} \mathrm{m}^{-3}$ ). The model predicts an increase in $\mathrm{Hg}$ (II) concentrations with altitude which is much smaller than observed (Fig. 2b). While underestimating the observed mean concentrations, the model captures the factor of 3-6 increase in $\mathrm{Hg}$ (II) in the "low RH" air mass categories relative to the "high RH" categories (Tables 3 and 4).

Figure 5 shows scatter plots between observed and modeled $\mathrm{Hg}$ (II) concentrations for the "low RH/low CO" and "low RH/high CO" categories. We find that the GEOS-Chem BASE simulation has a large negative $(-47$ to $-58 \%)$ normalized mean bias $\left(\mathrm{NMB}=\sum_{i}\left(M_{i}-O_{i}\right) / \sum_{i} O_{i}\right)$, where $O_{i}$ and $M_{i}$ are observed and simulated values, and for $O_{i}<\mathrm{DL}, \sum_{i} O_{i}$ is calculated using the ROS procedure). Furthermore, about $60 \%$ of modeled $\mathrm{Hg}$ (II) values are within a factor of two of the observations $(\mathrm{FAC} 2=$ fraction of points where $0.5 \leq M_{i} / O_{i} \leq 2$, for $O_{i} \leq \mathrm{DL}$, we assume $0.5 \leq$
$M_{i} / O_{i} \leq 2$ if $\left.M_{i}<2 \times \mathrm{DL}\right)$. If we consider only ADL observations, FAC2 decreases to $28-39 \%$.

Figure S2 (in the Supplement) displays scatterplots for the "high RH" categories. For ADL observations, the NMB is between -75 and $-94 \%$ for these categories (Fig. S2 and Table 4). We note that for these two "high RH" categories a conclusive evaluation of the model performance is difficult, however, because of the large fraction of BDL observations.

Considering the systematic model underestimate of observed $\mathrm{Hg}$ (II) concentrations, particularly in dry air masses where reduction and wet deposition are suppressed, we hypothesize that the bias in the $\mathrm{Hg}$ (II) concentrations is because the model simulated oxidation of $\mathrm{Hg}(0)$ to $\mathrm{Hg}(\mathrm{II})$ is too slow. We test this hypothesis in the next section by examining two sensitivity simulations.

\section{Sensitivity studies with enhanced $\mathrm{Hg}(0)$ oxidation}

As described in Sect. 2.3.4, we conduct two sensitivity simulations: in the $3 \times \mathrm{Br}$ simulation, we evaluate the model's response to an increase in $\mathrm{Br}$ concentrations, and in the FastK simulation, we evaluate the model's response to a faster oxidation rate constant. The results of these simulations are summarized in Table 4 and detailed comparisons to observations are presented in Figs. 4 and 5. Both the $3 \times \mathrm{Br}$ and FastK 

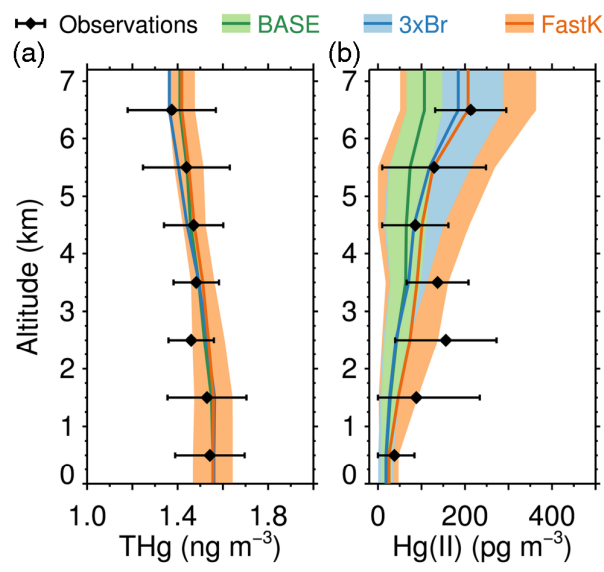

Figure 4. Mean vertical profiles of (a) $\mathrm{THg}$ and (b) $\mathrm{Hg}$ (II) concentrations averaged in $1 \mathrm{~km}$ vertical bins during NOMADSS. Observations are shown with black diamonds (error bars indicate the standard deviation). BDL $\mathrm{Hg}(\mathrm{II})$ observations are estimated using the ROS method for each vertical bin. The means and standard deviations for the three model simulations are shown as lines and shading: BASE (green), $3 \times \mathrm{Br}$ (blue), and FastK (orange).

simulations reproduce the observed mean concentration (Table 4) and vertical profile (Fig. 4a) of THg as we compensate the increase in $\mathrm{Hg}(0)$ oxidation with an increase in $\mathrm{Hg}(\mathrm{II})$ reduction rate to maintain the $\mathrm{THg}$ burden.

The $3 \times \mathrm{Br}$ and FastK simulations predict a stronger vertical gradient in $\mathrm{Hg}(\mathrm{II})$ concentrations, in closer agreement with observations (Fig. 4). Above $5 \mathrm{~km}, \mathrm{Hg}$ (II) concentrations in the $3 \times \mathrm{Br}\left(165 \pm 104 \mathrm{pg} \mathrm{m}^{-3}\right)$ and FastK $(184 \pm$ $156 \mathrm{pg} \mathrm{m}^{-3}$ ) simulations show significantly better agreement with observations $\left(189 \pm 103 \mathrm{pg} \mathrm{m}^{-3}\right)$ relative to the BASE simulation (97 $\pm 46 \mathrm{pg} \mathrm{m}^{-3}$ ) (Fig. 4b). For the "low RH/low CO" category, average modeled $\mathrm{Hg}(\mathrm{II})$ concentrations increase from $99 \pm 48 \mathrm{pg} \mathrm{m}^{-3}$ (BASE) to $162 \pm 104 \mathrm{pg} \mathrm{m}^{-3}$ $(3 \times \mathrm{Br})$ and $208 \pm 144 \mathrm{pg} \mathrm{m}^{-3}$ (FastK), compared to the observed $239 \pm 141 \mathrm{pg} \mathrm{m}^{-3}$. The modeled NMB for all $\mathrm{Hg}(\mathrm{II})$ observations in the "low RH/low CO" category decreases from $-58 \%$ (BASE simulation) to $-32 \%(3 \times \mathrm{Br})$ and $-12 \%$ (FastK), while the FAC2 index increases from $62 \%$ (BASE) to $69 \%(3 \times \mathrm{Br})$ and $80 \%($ FastK) (Fig. 5a-c). However, the sensitivity simulations cannot reproduce the high $\mathrm{Hg}$ (II) concentrations observed on RF-16 at 1-3 km (blue circles in Fig. 5). We present a detailed discussion of this flight in Sect. 6.

In the "low RH/high CO" category, the $3 \times \mathrm{Br} \mathrm{Hg}$ (II) concentrations $\left(91 \pm 67 \mathrm{pg} \mathrm{m}^{-3}\right)$ are $\sim 20 \%$ higher than the BASE model $\left(76 \pm 36 \mathrm{pg} \mathrm{m}^{-3}\right)$, but lower than the observed concentrations $\left(146 \pm 81 \mathrm{pg} \mathrm{m}^{-3}\right.$ ) (Table 4). In the FastK simulation, $\mathrm{Hg}(\mathrm{II})$ concentrations increase to $128 \pm 95 \mathrm{pg} \mathrm{m}^{-3}$, improving the NMB (FastK: $-11 \%, 3 \times \mathrm{Br}:-37 \%$, BASE: $-47 \%$ ) (Fig. $5 \mathrm{~d}-\mathrm{f}$ ). For this category, the $3 \times \mathrm{Br} \mathrm{Hg}$ (II) concentrations are not much higher than the BASE simulation

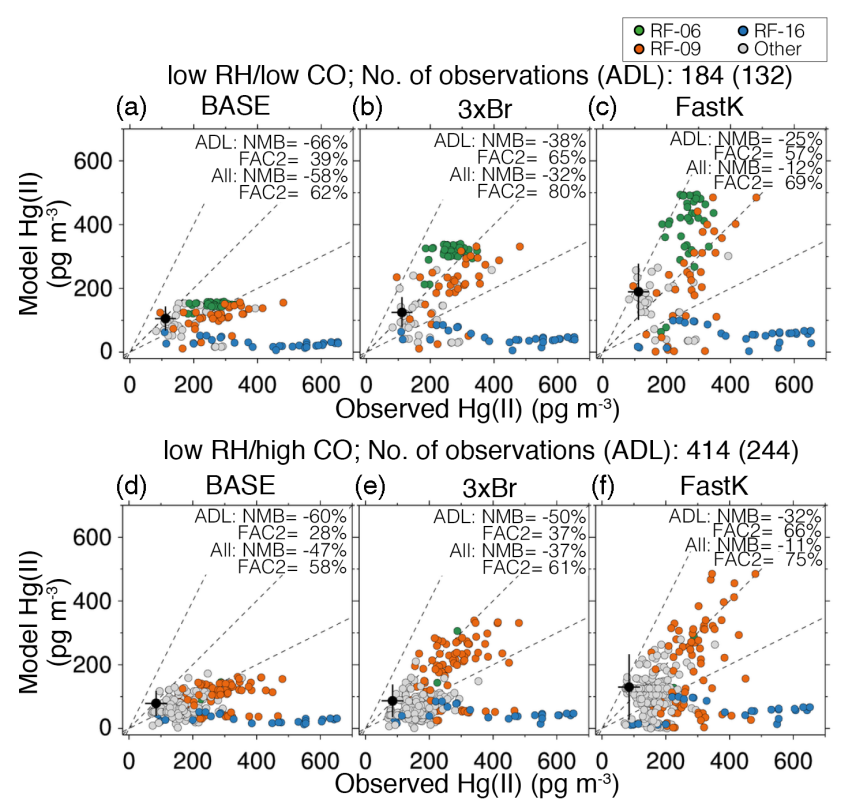

Figure 5. Scatterplot of observed and simulated concentrations of $\mathrm{Hg}$ (II) for the three model simulations in the (a-c) "low $\mathrm{RH} / \mathrm{low}$ CO”, and (d-f) "low RH/high CO" categories. Each column corresponds to our three GEOS-Chem simulations: BASE (left column), $3 \times \mathrm{Br}$ (middle column) and FastK (right column). Observations for RF-06 (green), RF-09 (orange), and RF-16 (blue) are highlighted in color, with the remaining observations indicated by gray symbols. The black circles and error bars represent the mean and standard deviations of values below the detection limit (BDL) estimated with the ROS method for each air mass category separately and the corresponding simulated concentrations. The Normalized Mean Bias (NMB) and fraction of points where the model is within a factor of 2 of the observations (FAC2) are indicated on each panel (see text for definitions).

because in the $3 \times \mathrm{Br}$ we use higher $\mathrm{Br}$ concentration only between $45^{\circ} \mathrm{N}$ and $45^{\circ} \mathrm{S}$, whereas most of the "low RH/high CO" air masses originated from high latitudes. The FAC2 index is higher in the FastK simulation (75\%) compared to the $\operatorname{BASE}(58 \%)$ and $3 \times \mathrm{Br}(61 \%)$ simulations.

Overall, the factor of 2 decrease in model bias for $\mathrm{Hg}(\mathrm{II})$ with the sensitivity simulations particularly for the "low $\mathrm{RH} /$ low CO" air samples suggests that the oxidation of $\mathrm{Hg}(0)$ in the upper troposphere is $3(3 \times \mathrm{Br})$ to 5 (FastK) times faster than what was considered previously in the GEOS-Chem model.

We ran two additional simulations that included oxidation by $\mathrm{OH} / \mathrm{O}_{3}$ and by $\mathrm{BrO}$, respectively, in addition to the $\mathrm{Br}$ initiated oxidation of the BASE version, to test whether the underestimate in the modeled oxidation results from exclusion of these oxidants. We add the following oxidation reactions to the model: 


\subsection{RF-06 (19 June 2013) and RF-09 (24 June 2013)}

$\mathrm{Hg}(0)+\mathrm{O}_{3} \rightarrow \mathrm{Hg}(\mathrm{II})$

$\mathrm{Hg}(0)+\mathrm{OH} \rightarrow \mathrm{Hg}(\mathrm{II})$

$\mathrm{Hg}(0)+\mathrm{BrO} \rightarrow \mathrm{Hg}(\mathrm{II})$

where $k_{5}=3.0 \times 10^{-20} \mathrm{~cm}^{3}$ molecule ${ }^{-1} \mathrm{~s}^{-1}$ (Hall, 1995), $k_{6}=8.7 \times 10^{-14} \mathrm{~cm}^{3}$ molecule ${ }^{-1} \mathrm{~s}^{-1}$ (Sommar et al., 2001), and $k_{7}=3.0 \times 10^{-14} \mathrm{~cm}^{3}$ molecule ${ }^{-1} \mathrm{~s}^{-1}$ (Spicer et al., 2002).

The inclusion of $\mathrm{Hg}(0)+\mathrm{O}_{3}$ and $\mathrm{Hg}(0)+\mathrm{OH}$ pathways decreases the global tropospheric chemical lifetime of $\mathrm{Hg}(0)$ for June-July 2013 from 3.2 months (BASE simulation) to 0.6 months, which is also lower than the lifetimes in the $3 \times \mathrm{Br}$ ( 1.9 months $)$ and the FastK $(0.7$ months $)$ simulations. However, the $\mathrm{Hg}(0)+\mathrm{O}_{3}$ and $\mathrm{Hg}(0)+\mathrm{OH}$ reaction pathways have a relatively small effect on the modeled $\mathrm{Hg}$ (II) concentrations in the upper troposphere. The 5-7 km Hg(II) concentrations in this simulation $\left(108 \pm 79 \mathrm{pg} \mathrm{m}^{-3}\right)$ are similar to the BASE simulation ( $\left.97 \pm 45 \mathrm{pg} \mathrm{m}^{-3}\right)$, but the $\mathrm{Hg}$ (II) concentrations below $5 \mathrm{~km}\left(71 \pm 51 \mathrm{pg} \mathrm{m}^{-3}\right)$ are higher than the BASE simulation $\left(39 \pm 33 \mathrm{pg} \mathrm{m}^{-3}\right)$. The increase in oxidation with the $\mathrm{Hg}(0)+\mathrm{O}_{3}$ and $\mathrm{Hg}(0)+\mathrm{OH}$ pathways is mostly in the lower troposphere, whereas in the upper troposphere, faster oxidation is compensated by faster reduction. While the oxidation rates of $\mathrm{Hg}(0)+\mathrm{O}_{3}$ and $\mathrm{Hg}(0)+\mathrm{OH}$ reactions have large uncertainties (see Sect. 1), our results indicate that the underestimate in $\mathrm{Hg}$ (II) concentrations in the BASE model persists despite the inclusion of the $\mathrm{Hg}(0)+\mathrm{O}_{3}$ and $\mathrm{Hg}(0)+\mathrm{OH}$ oxidation pathways.

When the $\mathrm{Hg}(0)+\mathrm{BrO}$ oxidation pathway is added, the June-July global tropospheric chemical lifetime of $\mathrm{Hg}(0)$ is 0.9 months. The simulated $5-7 \mathrm{~km} \mathrm{Hg}$ (II) concentrations $\left(115 \pm 75 \mathrm{pg} \mathrm{m}^{-3}\right)$ are higher than those in the BASE simulation, but not as high as the $3 \times \mathrm{Br}$ and FastK simulations, and much lower than the observations. The NMB for the "low $\mathrm{RH} /$ low CO" air masses is $-47 \%$ for this simulation, compared to $-32 \%$ for the $3 \times \mathrm{Br}$ simulation and $-12 \%$ for the FastK simulation. Thus, although including the $\mathrm{Hg}(0)+\mathrm{BrO}$ reaction with the rate from Spicer et al. (2002) brings the model closer to the observations, it does not completely explain the model underestimate of $\mathrm{Hg}$ (II) concentrations.

\section{Case studies of individual flights}

We analyze in more detail three NOMADSS flights during which high concentrations of $\mathrm{Hg}$ (II) were observed. For RF06 and RF-09 over Texas, we trace the origin of the high $\mathrm{Hg}$ (II) to transport from the subtropical Pacific anticyclone, while for RF-16 off the South Carolina Coast, enhanced $\mathrm{Hg}$ (II) concentrations appear to have been produced in the subtropical Atlantic anticyclone. The time series of the observations and model results along the flight tracks are shown in Figs. 6-8.
One of the goals of RF-06 was to sample in dry air masses with potentially enhanced $\mathrm{Hg}$ (II) concentrations. The meteorological forecasts indicated the presence of such an air mass at $6 \mathrm{~km}$ altitude over west Texas. After sampling in the boundary layer, the aircraft ascended to $6.8 \mathrm{~km}$ altitude, measuring $182-347 \mathrm{pg} \mathrm{m}^{-3}$ of $\mathrm{Hg}(\mathrm{II})$ between 18:02 and 19:47 UTC (Fig. 6a and d). The $\mathrm{Hg}$ (II) DL on this flight was $114 \mathrm{pg} \mathrm{m}^{-3}$, and quartz wool was used as the $\mathrm{Hg}$ (II) filter on the instrument's $\operatorname{Hg}(0)$ channel. The mean concentration of THg in this air mass was $1.35 \mathrm{ng} \mathrm{m}^{-3}$, about $20 \%$ lower than the $\mathrm{THg}$ concentrations measured during the rest of the flight (Fig. 6b). The observed low RH (11\%), CO (65 ppbv), $\mathrm{O}_{3}$ (39 ppbv), $\mathrm{NO}_{x}$ (53 pptv), $\mathrm{CH}_{2} \mathrm{O}$ (204 pptv), and $\mathrm{C}_{3} \mathrm{H}_{8}$ (36 pptv) indicate a clean and dry air mass (Fig. 6d). The 7-day HYSPLIT back trajectories (Fig. 6e) indicate that the air mass was transported from the subtropical Pacific anticyclone 3 days before it was sampled over Texas (see also Gratz et al., 2015a). The back trajectories show subsidence of the air mass from the upper troposphere $(10-12 \mathrm{~km}) \mathrm{be}$ fore transport out of the Pacific anticyclone.

Figure $6 \mathrm{c}$ shows that the $3 \times \mathrm{Br}$ simulation captures the enhancement in $\mathrm{Hg}$ (II) concentrations observed over Texas (observations: $251 \mathrm{pg} \mathrm{m}^{-3}, 3 \times \mathrm{Br}: 306 \mathrm{pg} \mathrm{m}^{-3}$ ), while the BASE model $\left(146 \mathrm{pg} \mathrm{m}^{-3}\right)$ is too low and the FastK model $\left(367 \mathrm{pg} \mathrm{m}^{-3}\right)$ too high. Outside the region with the high $\mathrm{Hg}(\mathrm{II})$ concentration, all three model simulations calculate $\mathrm{Hg}(\mathrm{II})$ concentrations that are BDL, and are in agreement with the observations. During this flight, observations indicate high $\mathrm{BrO}$ concentrations of $1.9 \pm 0.35 \mathrm{pptv}$ (Fig. 6d) (Gratz et al., 2015a). The GEOS-Chem modeled BrO concentrations in this air mass (0.3-0.4 pptv) are a factor of 5 lower than the observations (Fig. 6d), and thus our assumption of higher $\mathrm{Br}$ concentrations in the $3 \times \mathrm{Br}$ simulation is more consistent with these measurements (Sect. 2.3.4).

The transport pattern of dry air from the subtropical Pacific upper troposphere to the southeastern US persisted for several days and was sampled again on 24 June 2013 during flight RF-09 (Fig. 7a). High $\mathrm{Hg}$ (II) concentrations of 200$480 \mathrm{pg} \mathrm{m}^{-3}$ were measured between 16:00 and 19:30 UTC as the $\mathrm{C}-130$ aircraft flew five constant-altitude legs between 2.5 and $6.7 \mathrm{~km}$ over eastern Texas. The $\mathrm{Hg}(\mathrm{II}) \mathrm{DL}$ on this flight was $94 \mathrm{pg} \mathrm{m}^{-3}$, and quartz wool was used as the $\mathrm{Hg}$ (II) filter. Low $\mathrm{RH}(19 \%)$ and low $\mathrm{O}_{3}$ concentrations (50 ppbv) accompanied the high $\mathrm{Hg}$ (II) (Fig. 7c and d). BrO measurements are not available for this flight due to interference of clouds with the instrument. The HYSPLIT back trajectories show transport from the subtropical Pacific anticyclone (Fig. 7e), similar to RF-06. As the C-130 aircraft descended to $1.2 \mathrm{~km}$, high concentrations of $\mathrm{Hg}$ (II) (up to $360 \mathrm{pg} \mathrm{m}^{-3}$ ) were observed in the continental boundary layer between 19:30 and 20:00 UTC. This was associated with high THg concentrations of $2.0 \mathrm{ng} \mathrm{m}^{-3}$, and was likely due to emissions of both $\mathrm{Hg}(\mathrm{II})$ and $\mathrm{Hg}(0)$ from nearby sources. 
(a)

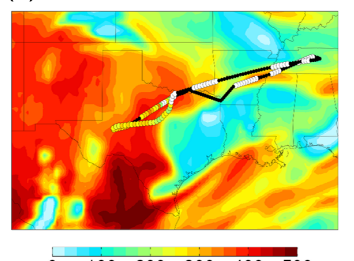

(e)

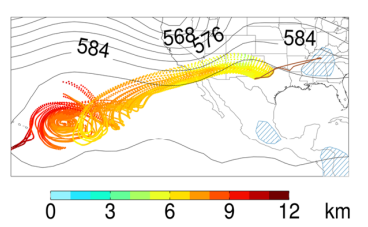

(b)
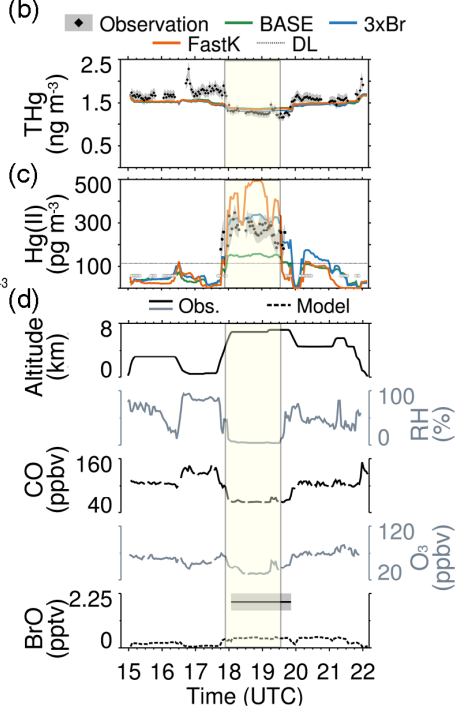

Figure 6. Case study for RF-06 on 19 June 2013. (a) The C-130 flight track with circles color-coded based on observed $\mathrm{Hg}$ (II) concentrations (locations along the flight track with no $\mathrm{Hg}$ (II) observations are filled in black, and below the detection limit (BDL) observations are filled in white). The background map displays the GEOS-Chem $\mathrm{Hg}$ (II) concentrations at $450 \mathrm{hPa}$ for the $3 \times \mathrm{Br}$ simulation between 17:00-20:00 UTC. The time series of the observations of $\mathrm{THg}$ and $\mathrm{Hg}(\mathrm{II})$ are shown in panels $(\mathbf{b}, \mathbf{c})$. The $\mathrm{THg}$ and $\mathrm{Hg}$ (II) measurements are represented by filled diamonds with the uncertainty represented by the gray shading. The dashed line represents the DL, and BDL observations are plotted at DL/2 with open circles. Modeled concentrations of $\mathrm{THg}$ and $\mathrm{Hg}$ (II) are displayed for the BASE (green line), $3 \times \mathrm{Br}$ (blue), and FastK (orange) simulations. Flight times where high $\mathrm{Hg}$ (II) concentrations were observed are highlighted. The time series of flight altitude, RH, CO, $\mathrm{O}_{3}$, and $\mathrm{BrO}$ (observations and model) are shown in panel (d). Panel (e) shows the 7-day HYSPLIT back trajectories for the highlighted sections of the flight. The contours show the NCEP/NCAR Reanalysis $500 \mathrm{hPa}$ geopotential heights on $18 \mathrm{Z}$ for the day of the flight. The hatched areas show regions with greater than an average of $10 \mathrm{~mm} \mathrm{day}^{-1}$ of surface precipitation for 7 days before the flight.

The mean THg concentrations for RF-09 calculated by the three simulations are between 1.38 and $1.42 \mathrm{ng} \mathrm{m}^{-3}$, and are close to the mean of the observations (Fig. 7b). Between 16:00 and 19:00 UTC, the $\mathrm{Hg}$ (II) concentrations calculated with the FastK model $\left(302 \mathrm{pg} \mathrm{m}^{-3}\right)$ are closer to the observations $\left(321 \mathrm{pg} \mathrm{m}^{-3}\right)$ than with the BASE $\left(127 \mathrm{pg} \mathrm{m}^{-3}\right)$ and $3 \times \mathrm{Br}\left(253 \mathrm{pg} \mathrm{m}^{-3}\right)$ models (Fig. 7c). However, between 19:00 and 19:30 UTC, the modeled $\mathrm{Hg}$ (II) concentrations for the three simulations are considerably lower $\left(40-60 \mathrm{pg} \mathrm{m}^{-3}\right)$ than the observed concentrations $\left(300 \mathrm{pg} \mathrm{m}^{-3}\right)$. The simulated RH (54\%) during this time was also higher than the observed RH (25\%). A comparison of the observed and modeled vertical profiles of isoprene (not shown) indicates an overestimate in the modeled local boundary layer depth,

(a)

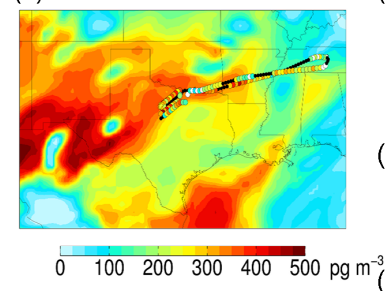

(b) Observation - BASE - 3xBr

(e)

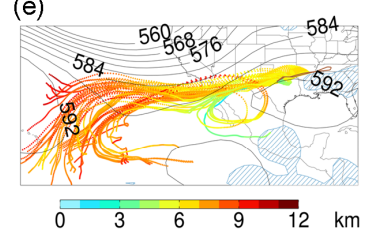

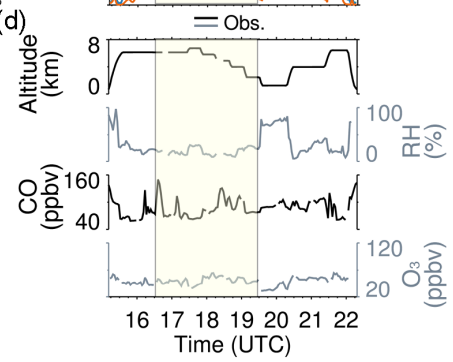

Figure 7. Case study for RF-09 on 24 June 2013. Same as Fig. 6, except that we do not show BrO concentrations which were not measured on this flight.

which could explain the difference between the model and the observations for this section of the flight.

For both RF-06 and RF-09, the GEOS-Chem simulations predict that the high observed $\mathrm{Hg}$ (II) concentrations were produced in the upper troposphere of the Pacific anticyclone. The upper troposphere is characterized by fast oxidation of $\mathrm{Hg}(0)$ to $\mathrm{Hg}(\mathrm{II})$ due to cold temperatures and higher $\mathrm{Br}$ concentrations. Furthermore, the cloud-free conditions within the anticyclones prevent removal of $\mathrm{Hg}$ (II) by deposition and aqueous reduction, leading to accumulation of $\mathrm{Hg}(\mathrm{II})$ (Sect. 8).

\subsection{RF-16 (8 July 2013)}

During RF-16, the aircraft flew to the South Carolina coast, with the goal of measuring the vertical distribution of mercury over the ocean (Fig. 8a). Of the eight constant altitude legs flown over the Atlantic, four were in the free troposphere, between 1.0 and $4.5 \mathrm{~km}$, and four were in the marine boundary layer (MBL). THg concentrations showed a slight decrease from the MBL $\left(1.58 \mathrm{ng} \mathrm{m}^{-3}\right)$ to the top of the vertical profile $\left(1.37 \mathrm{ng} \mathrm{m}^{-3}\right)$ (Fig. 8 b). $\mathrm{Hg}$ (II) was mostly BDL in the MBL, but was high in the free troposphere reaching up to $680 \mathrm{pg} \mathrm{m}^{-3}$ with a mean concentration of $450 \mathrm{pg} \mathrm{m}^{-3}$ (Fig. 8c). The $\mathrm{Hg}$ (II) DL on this flight was $91 \mathrm{pg} \mathrm{m}^{-3}$, and the $\mathrm{Hg}$ (II) filter was a cation exchange membrane. The free-tropospheric air had a low concentration of $\mathrm{CO}$ (65 ppbv) and low RH (33\%) (Fig. 8d). The $\mathrm{CHBr}_{3}$ concentration was about $1 \mathrm{pptv}$ in the free tropospheric air, compared to about 2 pptv in the MBL. In consistency with the low $\mathrm{RH}$ and $\mathrm{CHBr}_{3}$, the HYSPLIT back trajectories show slow subsidence of the air mass from 4-6 km altitude in the subtropical Bermuda anticyclone (Fig. 8e). 


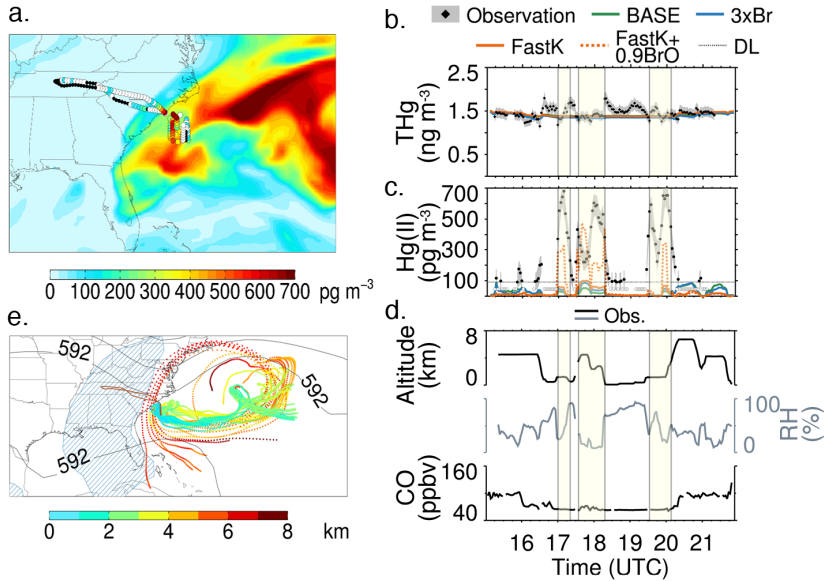

Figure 8. Case study for RF-16 on 8 July 2013. Same as Fig. 6, except the background map (a) displays $\mathrm{Hg}(\mathrm{II})$ concentrations at $800 \mathrm{hPa}$ for the FastK $+0.9 \mathrm{BrO}$ pptv simulation. Also we add the FastK +0.9 ppt simulation as an orange dashed line in panels $(\mathbf{b}, \mathbf{c})$. $\mathrm{O}_{3}$ concentrations were not available for this flight and $\mathrm{BrO}$ concentrations were below the instrument's detection limit.

The simulated THg concentrations in the MBL (1.34$\left.1.38 \mathrm{ng} \mathrm{m}^{-3}\right)$ are lower than the observations $\left(1.58 \mathrm{ng} \mathrm{m}^{-3}\right)$, suggesting an underestimate in the ocean emission flux (Song et al., 2015) or an overestimate in the deposition flux (Fig. 8b). None of the model simulations capture the enhancements in $\mathrm{Hg}(\mathrm{II})$ observed between 17:00 and 18:15 UTC, and again between 19:30 and 20:15 UTC (Fig. 8c). During this flight, observed $\mathrm{BrO}$ concentrations remained below the instrument's DL of 0.9 pptv, and the modeled $\mathrm{BrO}$ concentrations were $0.1-0.3$ pptv. We performed an additional simulation increasing the modeled $\mathrm{BrO}$ concentrations in the free troposphere of the Bermuda anticyclone to $0.9 \mathrm{pptv}$ (with a proportional increase in $\mathrm{Br}$ radical concentrations) for the FastK simulation ( $\mathrm{FastK}+0.9 \mathrm{BrO}$ ). The resulting $\mathrm{Hg}$ (II) concentrations along the flight track increase to $150-500 \mathrm{pg} \mathrm{m}^{-3}$, in better agreement with the observations (Fig. 8c). The oxidation of $\mathrm{Hg}(0)$ in this air mass was considerably faster than the $3 \times \mathrm{Br}$ or FastK simulations, which suggests that the uncertainties in both the $\mathrm{Br}$ radical concentrations and in the oxidation rate constant can simultaneously affect the overall bias in the modeled $\mathrm{Hg}$ (II) in certain areas.

\section{$7 \quad$ Links to previous studies}

The above comparison of the simulated $\mathrm{Hg}$ (II) concentrations with the NOMADSS observations shows that the $\mathrm{Hg}(0)$ oxidation based on the standard rate constants (Goodsite et al., 2004, 2012; Donohoue et al., 2006) and the GEOSChem calculated $\mathrm{Br}$ concentrations is too slow. Increasing the free tropospheric $\mathrm{Br}$ concentrations by a factor of 3 or considering the higher rate constants of Ariya et al. (2002) leads to significant improvement in the model results in the free troposphere compared to the NOMADSS observations. By contrast, Weiss-Penzias et al. (2015) found that the GEOS-Chem simulated $\mathrm{Hg}$ (II) concentrations in the free troposphere were 2.5 times higher on average than the observed concentrations at five high-elevation sites in western USA and Taiwan. Differences in the instruments and models used in their study and ours make it difficult to directly compare our findings. Weiss-Penzias et al. (2015) used the Tekran ${ }^{\circledR}$ 2537-11301135 system, which can underestimate $\mathrm{Hg}$ (II) in the presence of $\mathrm{O}_{3}$ (Lyman et al., 2010; McClure et al., 2014). Their GEOS-Chem model is based on the reaction kinetics described in Holmes et al. (2010) and does not include updates described in Sect. 2.3.3. Importantly, the rate constant for the dissociation of $\mathrm{HgBr}$ (Reaction R2) has since been corrected, and is now a factor of 10-20 higher than the previous value. The faster rate of dissociation of $\mathrm{HgBr}$ decreases the modeled $\mathrm{Hg}$ (II) concentration at $600 \mathrm{hPa}$ by a factor of about 1.5 .

The relatively high DL of the UW-DOHGS instrument makes the NOMADSS observations unsuitable for an evaluation of faster oxidation in the boundary layer. However, three previous studies in the tropical and mid-latitude MBL have reported similar findings that the standard $\mathrm{Hg}(0)+\mathrm{Br}$ oxidation kinetics are too slow to reproduce the observed $\mathrm{Hg}$ (II) concentrations, as discussed below.

Sprovieri et al. (2010) observed the diurnal cycle in RGM concentrations over the Adriatic Sea with daily enhancements of $20-40 \mathrm{pg} \mathrm{m}^{-3}$ at midday. Using a box model, the authors found that they could reasonably reproduce the observations with the Ariya et al. (2002) rate constant for the $\mathrm{Hg}(0)+\mathrm{Br}$ reaction (Reaction $\mathrm{R} 1$ ), but only if the $\mathrm{HgBr}$ thermal dissociation (Reaction R2) was neglected. In their study, $\mathrm{Br}$ was considered to be the sole second-step oxidant (Reaction R4). If $\mathrm{HO}_{2}, \mathrm{NO}_{2}$, and $\mathrm{BrO}$ were to be included as second-step oxidants (Dibble et al., 2012), as we do in our FastK simulation, it would provide an additional pathway for the oxidation of $\mathrm{HgBr}$ to $\mathrm{Hg}(\mathrm{II})$, and partly overcome the slowing effect of the $\mathrm{HgBr}$ thermal dissociation.

In analyzing RGM observations over the Galapagos Islands in the equatorial Pacific, Wang et al. (2014) showed that the inclusion of $\mathrm{HO}_{2}$ and $\mathrm{NO}_{2}$ as second-step oxidants in the $\mathrm{Hg}(0)+\mathrm{Br}$ reaction scheme based on Goodsite et al. (2012) and Dibble et al. (2012) was necessary to simulate the observed magnitude of the midday peaks in RGM concentrations. The box modeling study assumed peak daytime $\mathrm{BrO}$ concentrations of $0.2 \mathrm{pptv}$, which is similar to the annual average GEOS-Chem $\mathrm{BrO}$ concentration of 0.14 pptv. However, because of the uncertainties in the Tekran ${ }^{\circledR} 2537$ 1130-1135 system measurements, the actual concentrations of $\mathrm{Hg}$ (II) could possibly be higher than the observed concentrations (Wang et al., 2014; Lyman et al., 2010; Ambrose et al., 2013).

Tas et al. (2012) present an analysis of mercury depletion events associated with extremely high $\mathrm{BrO}$ concentrations (20-80 pptv) over the Dead Sea in Israel. They found that 
the standard Br-initiated mechanism was insufficient to reproduce the rate of depletion of $\mathrm{Hg}(0)$ and showed that oxidation of $\mathrm{Hg}(0)$ by $\mathrm{BrO}$, at a rate close to that reported by Spicer et al. (2002), was necessary to explain the loss of $\mathrm{Hg}(0)$. If the FastK kinetics are considered, the Br-initiated pathway by itself can explain a large fraction of observed depletion rate of $\mathrm{Hg}(0)$. Although the $\mathrm{BrO}$ oxidation pathway cannot be entirely ignored (as discussed in Sect. 5), its importance, in this case, would be much smaller than what was found by Tas et al. (2012). Overall, these MBL studies are consistent with our analysis of the NOMADSS free tropospheric observations in implying much faster tropospheric oxidation of $\mathrm{Hg}(0)$ than currently assumed.

\section{Implications of faster oxidation in the GEOS-Chem model}

The global annual tropospheric mercury budgets for the three simulations are presented in Fig. 9. Despite faster oxidation in the $3 \times \mathrm{Br}$ and FastK simulations, we maintain the same global burden of $\mathrm{THg}$ by increasing the $\mathrm{Hg}$ (II) reduction rate (Sect. 2.3.4). Thus, the lifetime of $\mathrm{THg}$ against deposition is similar in all three simulations ( $\sim 8.5$ months). While we acknowledge that the modeled burden and lifetime of $\mathrm{THg}$ are affected by the uncertainty in the emission and deposition fluxes of mercury (Lin et al., 2006; Selin, 2009), we choose to maintain these in the three simulations because it allows us to focus on the model's sensitivity to redox kinetics.

The tropospheric oxidation of $\mathrm{Hg}(0)$ to $\mathrm{Hg}(\mathrm{II})$ increases from $10900 \mathrm{Mga}^{-1}$ in the BASE simulation, to $18300 \mathrm{Mga}^{-1}$ for $3 \times \mathrm{Br}$ (factor of 1.7 increase) and $42100 \mathrm{Mg} \mathrm{a}^{-1}$ (factor of 3.9 increase) for the FastK simulation. The lifetime of $\mathrm{Hg}(0)$ against oxidation to $\mathrm{Hg}(\mathrm{II})$ decreases from 5 months in the BASE simulation to 2.81.2 months in the $3 \times \mathrm{Br}$ and FastK simulations. The tropospheric burden of $\mathrm{Hg}(\mathrm{II})$ increases by $33 \%$ in the $3 \times \mathrm{Br}$ simulation and by $66 \%$ in the FastK simulations.

Compared to the BASE simulation, the lifetime of $\mathrm{Hg}$ (II) against reduction decreases from 35 days (BASE simulation) to 19 days $(3 \times \mathrm{Br})$ and 8 days $(\mathrm{FastK})$ simulations, respectively. This results in faster cycling between $\mathrm{Hg}(0)$ and $\mathrm{Hg}(\mathrm{II})$. Globally, $48 \%$ of the $\mathrm{Hg}$ (II) formed in the troposphere in the BASE simulation is reduced back to $\mathrm{Hg}(0)$ (Fig. 9a), whereas in the $3 \times \mathrm{Br}$ and FastK simulations, that fraction increases to $68-88 \%$ (Fig. 9b and c). The faster reduction in the simulations with faster oxidation implies that reduction plays a predominant role in controlling the burden and distribution of $\mathrm{Hg}(\mathrm{II})$ in the atmosphere. In view of our poor understanding of $\mathrm{Hg}$ (II) reduction in the atmosphere (Subir et al., 2011), we suggest that further laboratory and field measurements be conducted to constrain this process.

In this study, we chose to increase the reduction rate of $\mathrm{Hg}(\mathrm{II})$ to maintain the global burden of $\mathrm{THg}$ when oxidation is enhanced in $3 \times \mathrm{Br}$ and FastK simulations. An alternative
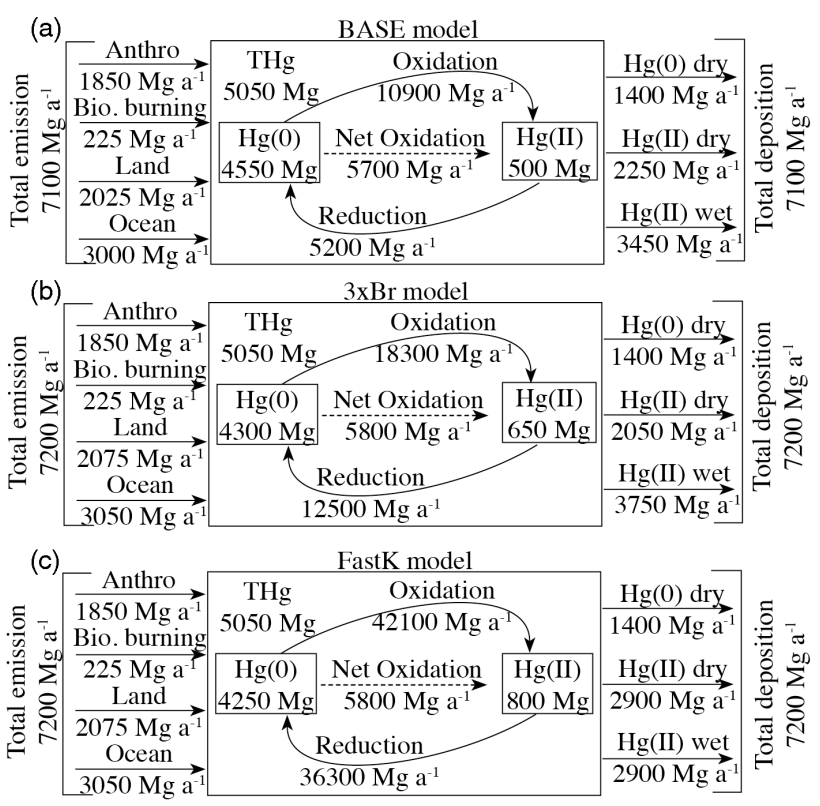

Figure 9. Annual global tropospheric budget of mercury in the (a) BASE, (b) $3 \times \mathrm{Br}$, and (c) FastK simulations for 2013. The burdens are in units of $\mathrm{Mg}\left(10^{6} \mathrm{~g}\right)$ and the fluxes are in units of $\mathrm{Mg} \mathrm{a}^{-1}$ (Mg per year).

approach would have been to keep the reduction rate constant and increase the global emissions of THg by factors of 2 to 4. Such a large increase exceeds the range of reported emission estimates (Selin, 2009; Song et al., 2015; Pirrone et al., 2010), and thus we did not consider it. Moreover, this would lead to a 2 to 4 -fold decrease in the lifetime of THg against deposition which is not supported by the nearly constant vertical profiles of $\mathrm{THg}$ observed in the troposphere during NOMADSS and other aircraft campaigns (Holmes et al., 2010).

Figure 10 shows the simulated distribution of $\mathrm{Hg}(\mathrm{II})$ at $450 \mathrm{hPa}(6.5 \mathrm{~km})$ for 1 June-15 July 2013. In all three simulations, $\mathrm{Hg}(\mathrm{II})$ is enhanced in the subtropical anticyclones, with larger enhancements in the $3 \times \mathrm{Br}$ and the FastK simulations (Fig. 10a-c). A vertical profile in the Pacific subtropical anticyclone (Box 1, Fig. 10d) shows that the increase occurs throughout the free troposphere (Fig. 10d). Over the eastern US (Fig. 10e), the free tropospheric $\mathrm{Hg}$ (II) vertical profiles are similar for the three simulations below $8 \mathrm{~km}$, where on average the increase in oxidation is matched by the increase in aqueous phase reduction in clouds. Above $8 \mathrm{~km}$, the absence of liquid clouds prevents reduction from compensating for faster oxidation, and $\mathrm{Hg}$ (II) concentrations in the $3 \times \mathrm{Br}$ and FastK simulations are higher. Thus, the increase in the global $\mathrm{Hg}(\mathrm{II})$ mass burden in the $3 \times \mathrm{Br}$ and FastK simulations is concentrated largely in the subtropical anticyclones, and, to a smaller extent, in the extra-tropical upper troposphere. 


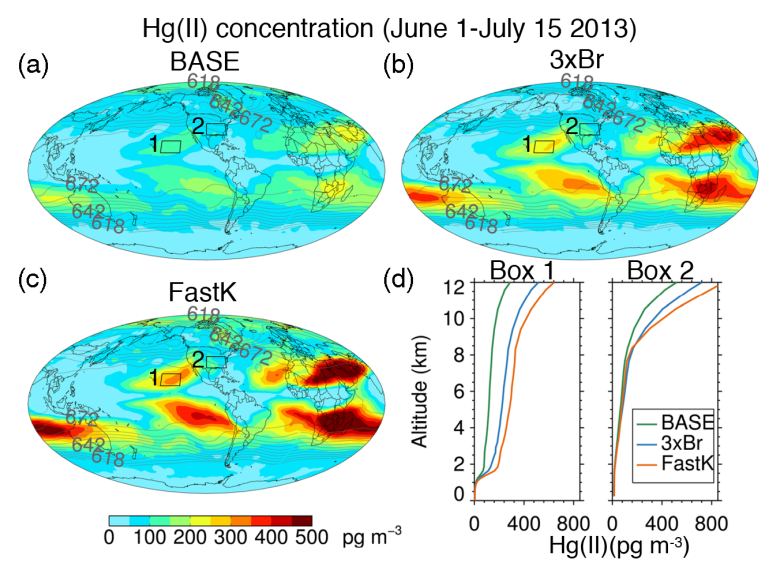

Figure 10. Average concentration of $\mathrm{Hg}(\mathrm{II})$ at $450 \mathrm{hPa}$ during NOMADSS (1 June to 15 July 2013) for the (a) BASE, (b) $3 \times \mathrm{Br}$, and (c) FastK simulations. The contours show the NCEP/NCAR Reanalysis $450 \mathrm{hPa}$ geopotential height averaged over the same period (contour interval: 6 decameter). Panel (d) indicates the mean modeled vertical profiles of $\mathrm{Hg}$ (II) concentrations for regions marked as "Box 1" and "Box 2" for the three simulations (BASE: green, $3 \times \mathrm{Br}$ : blue, FastK: orange).

Two processes maintain the high modeled $\mathrm{Hg}$ (II) concentrations in the subtropical anticyclones. First, the anticyclones are characterized by large-scale sinking motion which transports higher $\mathrm{Hg}(\mathrm{II})$ concentrations from the upper troposphere where fast oxidation of $\mathrm{Hg}(0)$ results from higher $\mathrm{Br}$ concentrations and lower temperatures slowing the thermal dissociation of the $\mathrm{HgBr}$ intermediate (Reaction R2). The locations of the $450 \mathrm{hPa}$ enhancements in $\mathrm{Hg}$ (II) concentrations displayed in Fig. 10 are thus largely associated with the descending branches of the Hadley circulation. Note that the model predicts larger $\mathrm{Hg}$ (II) concentrations in the Southern Hemisphere subtropics where the winter Hadley circulation is stronger. Second, the sinking air in the anticyclones suppresses cloud formation and precipitation, thereby preventing loss of $\mathrm{Hg}$ (II) by reduction and wet deposition. This leads to efficient accumulation of $\mathrm{Hg}$ (II) in the subtropical anticyclones, even at lower altitudes. The model predicts low $450 \mathrm{hPa} \mathrm{Hg}$ (II) concentrations in regions in the tropics with high cloud cover and precipitation (such as the Western Pacific), and in regions with low insolation, such as the Southern (winter) Hemisphere polar region.

The model simulates frequent episodes of high $\mathrm{Hg}$ (II) concentrations at $6.5 \mathrm{~km}$ over Texas during the summer of 2013 (Fig. 11a). From 1 June to 15 July, simulated midday (noon3 p.m.) $\mathrm{Hg}$ (II) concentrations were higher than $250 \mathrm{pg} \mathrm{m}^{-3}$ for 15 days in the FastK simulation $(3 \times \mathrm{Br}$ : 12 days), two of which were the days when RF-06 and RF-09 were conducted. RF-10 also flew at $7 \mathrm{~km}(425 \mathrm{hPa})$ over northern Texas and Oklahoma (Fig. 1) on 27 June 2013, but observed $\mathrm{Hg}$ (II) concentrations remained BDL (DL: $134 \mathrm{pg} \mathrm{m}^{-3}$ ) during the high altitude leg. The $3 \times \mathrm{Br}$ and FastK modeled

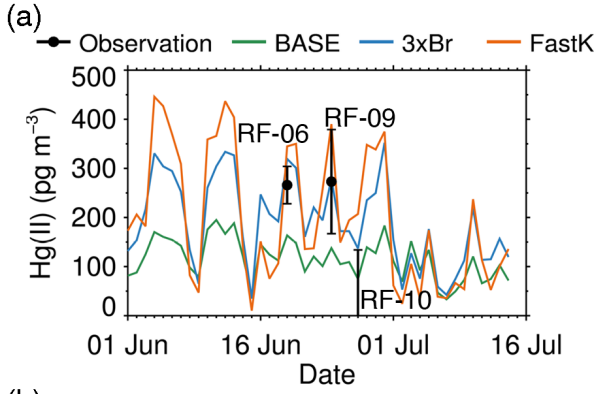

(b)

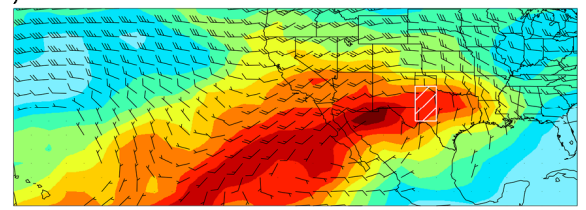

(c)

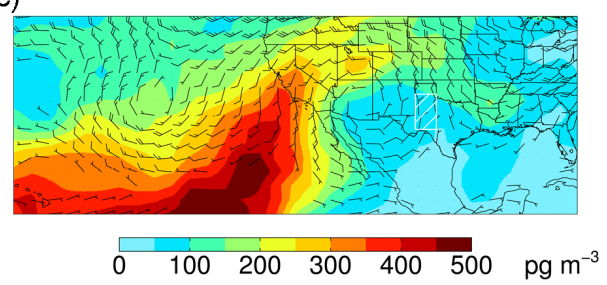

Figure 11. (a) Modeled time series of midday (noon-3 p.m.) $\mathrm{Hg}$ (II) concentrations at $6.5 \mathrm{~km}$ altitude over Texas (white rectangle shown in panels $\mathbf{b}, \mathbf{c}$ ) for the three GEOS-Chem simulations (BASE: green, $3 \times$ Br: blue, FastK: orange) for 1 June-15 July 2013 and the mean and standard deviations of $\mathrm{Hg}(\mathrm{II})$ observations at 6-7 km over Texas for RF-06, RF-09 and RF-10. (b) Mean midday FastK Hg(II) concentrations and winds at $6.5 \mathrm{~km}$ altitude for the 10 highest FastK $\mathrm{Hg}$ (II) concentrations from the time series in panel (a). (c) Mean midday FastK $\mathrm{Hg}$ (II) concentrations for the 10 days with the lowest $\mathrm{Hg}(\mathrm{II})$ concentrations.

$\mathrm{Hg}(\mathrm{II})$ concentrations over this region during RF-10 were 136 and $208 \mathrm{pg} \mathrm{m}^{-3}$, respectively, significantly lower than those simulated for RF-06 and RF-09. The highest $\mathrm{Hg}$ (II) at $6.5 \mathrm{~km}$ over Texas and Oklahoma occurs when the wind over the southern US is southwesterly (Fig. 11b) transporting $\mathrm{Hg}$ (II) from the semi-permanent Pacific anticyclone, whereas the lowest concentrations occur when the transport is from the north (Fig. 11c). Our results suggest that the transport of $\mathrm{Hg}(\mathrm{II})$ produced in the Pacific anticyclone could be an important source of $\mathrm{Hg}$ (II) over southeastern US, potentially influencing wet deposition in the region if these high $\mathrm{Hg}(\mathrm{II})$ air masses are exposed to deep convection.

\section{Conclusions}

In this work, we have analyzed aircraft-based measurements of atmospheric mercury species ( $\mathrm{THg}$ and $\mathrm{Hg}(\mathrm{II})$ ) made during the NOMADSS campaign that took place over the southeastern US during summer 2013. The THg observations show a weak vertical gradient with higher concentrations in 
the bottom $1 \mathrm{~km}\left(1.54 \mathrm{ng} \mathrm{m}^{-3}\right)$, and lower concentrations between 6 and $7 \mathrm{~km}\left(1.38 \mathrm{ng} \mathrm{m}^{-3}\right)$ in the atmosphere.

During NOMADSS, the mean $\mathrm{Hg}$ (II) concentrations observed above the instrument's limit of detection was $212( \pm 112) \mathrm{pg} \mathrm{m}^{-3}$. Using the robust regression on order statistics procedure, the estimated mean $\mathrm{Hg}$ (II) concentration for all observations was $110( \pm 103) \mathrm{pg} \mathrm{m}^{-3}$. The highest $\mathrm{Hg}$ (II) concentrations, 300-680 $\mathrm{pg} \mathrm{m}^{-3}$, were seen at 5-7 km altitude during two flights over Texas and at $1-3 \mathrm{~km}$ during one flight over the Atlantic Ocean. These high $\mathrm{Hg}$ (II) concentrations were associated with clean subsiding air masses originating in the upper troposphere within the Pacific or Atlantic anticyclones. The low temperatures and high concentrations of the bromine radical in the upper troposphere lead to faster oxidation of $\mathrm{Hg}(0)$, while the lack of removal from in-cloud reduction or wet deposition in the dry anticyclones lead to efficient accumulation of $\mathrm{Hg}$ (II).

We used the GEOS-Chem model to evaluate the oxidation kinetics and interpret these observations. The modeled THg concentrations are in close agreement with the observations, reproducing the horizontal and vertical distribution of $\mathrm{THg}$. The simulated $\mathrm{Hg}(\mathrm{II})$ concentrations, on the other hand, are a factor of 2.2 lower than the observed concentrations. We attribute this systematic bias to an underestimate in the modeled oxidation of $\mathrm{Hg}(0)$ to $\mathrm{Hg}(\mathrm{II})$.

We perform two additional simulations with (i) three times the $\mathrm{Br}$ radical concentrations between $45^{\circ} \mathrm{N}$ and $45^{\circ} \mathrm{S}$ and between $750 \mathrm{hPa}$ and the tropopause $(3 \times \mathrm{Br})$, and (ii) a faster $\mathrm{Hg}(0)+\mathrm{Br}$ oxidation rate constant (FastK). The model performance improves with both these simulations, especially above $5 \mathrm{~km}$ altitude and in air masses with low RH $(<35 \%)$ and low $\mathrm{CO}(<75 \mathrm{ppbv})$, where some of the highest $\mathrm{Hg}$ (II) concentrations were observed. For these air masses, the $\mathrm{Hg}$ (II) concentrations simulated with the $3 \times \mathrm{Br}$ $\left(162 \pm 104 \mathrm{pg} \mathrm{m}^{-3}\right)$ and the FastK $\left(208 \pm 144 \mathrm{pg} \mathrm{m}^{-3}\right)$ models are $60-100 \%$ higher than the BASE simulation $(99 \pm$ $48 \mathrm{pg} \mathrm{m}^{-3}$ ) and in closer agreement with the observations $\left(239 \pm 141 \mathrm{pg} \mathrm{m}^{-3}\right)$. In addition to oxidation of $\mathrm{Hg}(0)$ by $\mathrm{Br}$ (BASE case), we considered the effect of including $\mathrm{O}_{3}$ and $\mathrm{OH}$ as oxidants, but found that the high $\mathrm{Hg}$ (II) concentrations observed at 5-7 $\mathrm{km}$ could not be reproduced. We also examined the effect of adding the $\mathrm{Hg}(0)+\mathrm{BrO}$ reaction to the BASE simulation, and found that the model underestimate of $\mathrm{Hg}(\mathrm{II})$ at 5-6 $\mathrm{km}$ persisted. Our modeling study suggests that the NOMADSS observations are most consistent with the $3 \times \mathrm{Br}$ simulation and the FastK simulation, however we note that the relative importance of the different oxidation pathways cannot be ascertained before the chemical forms of $\mathrm{Hg}$ (II) in the atmosphere have been identified.

Faster oxidation decreases the lifetime of $\operatorname{Hg}(0)$ against oxidation from 5 months in the BASE simulation to 2.8 months with the $3 \times \mathrm{Br}$ simulation, and to 1.2 months with the FastK simulation. To maintain the global THg burden, the faster modeled $\mathrm{Hg}(0)$ oxidation is balanced by an increase in the modeled $\mathrm{Hg}(\mathrm{II})$ reduction rates. The contribution of re- duction to the overall loss of $\mathrm{Hg}$ (II) (by deposition and reduction) increases from $48 \%$ in the BASE simulation to 68 and $88 \%$ in the $3 \times \mathrm{Br}$ and the FastK simulations, respectively, implying a greater importance of reduction to chemistry of mercury in the atmosphere. In the subtropical anticyclones, the $3 \times \mathrm{Br}$ and FastK simulations predict a 3 to 5 -fold enhancement in $\mathrm{Hg}$ (II) concentrations at $450 \mathrm{hPa}$ relative to the global average $\mathrm{Hg}$ (II) concentration. These subtropical anticyclones are dry, cloud-free regions which provide ideal conditions for accumulation of $\mathrm{Hg}$ (II). The high $\mathrm{Hg}$ (II) in the Pacific anticyclone is periodically transported over southern US during summer and could be an important source of mercury wet deposition in the region. Future measurements in the subtropical anticyclones can help us gain deeper insights into the pathways of $\operatorname{Hg}(0)$ oxidation in the atmosphere.

\section{The Supplement related to this article is available online at doi:10.5194/acp-16-1511-2016-supplement.}

Acknowledgements. This material is based upon work supported by the National Science Foundation under grant no. 1217010 to D. A. Jaffe, L. Jaeglé and N. E. Selin, grant no. 1215712 to J. Stutz, and grant no. 1216743 to C. A. Cantrell and R. L. Mauldin III. The authors thank participants from National Center for Atmospheric Research's Earth Observing Laboratory and Research Aviation Facility for their support in the planning and execution of the NOMADSS campaign.

Edited by: A. Dastoor

\section{References}

Ambrose, J. L., Lyman, S. N., Huang, J., Gustin, M. S., and Jaffe, D. A.: Fast time resolution oxidized mercury measurements during the Reno Atmospheric Mercury Intercomparison Experiment (RAMIX), Environ. Sci. Technol., 47, 7285-7294, doi:10.1021/es303916v, 2013.

Ambrose, J. L., Gratz, L. E., Jaffe, D. A., Campos, T., Flocke, F. M., Knapp, D. J., Stechman, D. M., Stell, M., Weinheimer, A., Cantrell, C., and Mauldin, R. L.: Mercury emission ratios from coal-fired power plants in the southeastern U.S. during NOMADSS, Environ. Sci. Technol., 49, 10389-10397, doi:10.1021/acs.est.5b01755, 2015.

Amos, H. M., Jacob, D. J., Holmes, C. D., Fisher, J. A., Wang, Q., Yantosca, R. M., Corbitt, E. S., Galarneau, E., Rutter, A. P., Gustin, M. S., Steffen, A., Schauer, J. J., Graydon, J. A., Louis, V. L. St., Talbot, R. W., Edgerton, E. S., Zhang, Y., and Sunderland, E. M.: Gas-particle partitioning of atmospheric $\mathrm{Hg}(\mathrm{II})$ and its effect on global mercury deposition, Atmos. Chem. Phys., 12, 591-603, doi:10.5194/acp-12-591-2012, 2012.

Amos, H. M., Jacob, D. J., Streets, D. G., and Sunderland, E. M.: Legacy impacts of all-time anthropogenic emissions on the global mercury cycle, Global Biogeochem. Cy., 27, 410-421, doi:10.1002/gbc.20040, 2013. 
Apel, E. C., Emmons, L. K., Karl, T., Flocke, F., Hills, A. J., Madronich, S., Lee-Taylor, J., Fried, A., Weibring, P., Walega, J., Richter, D., Tie, X., Mauldin, L., Campos, T., Weinheimer, A., Knapp, D., Sive, B., Kleinman, L., Springston, S., Zaveri, R., Ortega, J., Voss, P., Blake, D., Baker, A., Warneke, C., Welsh-Bon, D., de Gouw, J., Zheng, J., Zhang, R., Rudolph, J., Junkermann, W., and Riemer, D. D.: Chemical evolution of volatile organic compounds in the outflow of the Mexico City Metropolitan area, Atmos. Chem. Phys., 10, 2353-2375, doi:10.5194/acp-10-23532010, 2010.

Ariya, P. A., Khalizov, A., and Gidas, A.: Reactions of gaseous mercury with atomic and molecular halogens: kinetics, product studies, and atmospheric implications, J. Phys. Chem. A, 106, 7310 7320, doi:10.1021/jp020719o, 2002.

Balabanov, N. B., Shepler, B. C., and Peterson, K. A.: Accurate global potential energy surface and reaction dynamics for the ground state of $\mathrm{HgBr}_{2}$, J. Phys. Chem. A, 109, 8765-8773, doi:10.1021/jp0534151, 2005.

Bey, I., Jacob, D. J., Yantosca, R. M., Logan, J. A., Field, B. D., Fiore, A. M., Li, Q., Liu, H. Y., Mickley, L. J., and Schultz, M. G.: Global modeling of tropospheric chemistry with assimilated meteorology: model description and evaluation, J. Geophys. Res.-Atmos., 106, 23073-23095, doi:10.1029/2001jd000807, 2001.

Brooks, S., Ren, X., Cohen, M., Luke, W. T., Kelley, P., Artz, R., Hynes, A., Landing, W., and Martos, B.: Airborne vertical profiling of mercury speciation near Tullahoma, TN, USA, Atmosphere, 5, 557-574, doi:10.3390/atmos5030557, 2014.

Bullock, O. R., Atkinson, D., Braverman, T., Civerolo, K., Dastoor, A., Davignon, D., Ku, J.-Y., Lohman, K., Myers, T. C., Park, R. J., Seigneur, C., Selin, N. E, Sistla, G., and Vijayaraghavan, K.: The North American Mercury Model Intercomparison Study (NAMMIS): study description and modelto-model comparisons, J. Geophys. Res.-Atmos., 113, D17310, doi:10.1029/2008jd009803, 2008.

Bullock, O. R., Atkinson, D., Braverman, T., Civerolo, K., Dastoor, A., Davignon, D., Ku, J.-Y., Lohman, K., Myers, T. C., Park, R. J., Seigneur, C., Selin, N. E, Sistla, G., and Vijayaraghavan, K.: An analysis of simulated wet deposition of mercury from the North American Mercury Model Intercomparison Study, J. Geophys. Res.-Atmos., 114, D08301, doi:10.1029/2008jd011224, 2009.

Calvert, J. G. and Lindberg, S. E.: Mechanisms of mercury removal by $\mathrm{O}_{3}$ and $\mathrm{OH}$ in the atmosphere, Atmos. Environ., 39, 33553367, doi:10.1016/j.atmosenv.2005.01.055, 2005.

Dibble, T. S., Zelie, M. J., and Mao, H.: Thermodynamics of reactions of $\mathrm{ClHg}$ and $\mathrm{BrHg}$ radicals with atmospherically abundant free radicals, Atmos. Chem. Phys., 12, 10271-10279, doi:10.5194/acp-12-10271-2012, 2012.

Donohoue, D. L., Bauer, D., Cossairt, B., and Hynes, A. J.: Temperature and pressure dependent rate coefficients for the reaction of $\mathrm{Hg}$ with $\mathrm{Br}$ and the reaction of $\mathrm{Br}$ with $\mathrm{Br}$ : a pulsed laser photolysis-pulsed laser induced fluorescence study, J. Phys. Chem. A, 110, 6623-6632, doi:10.1021/jp054688j, 2006.

Draxler, R. R. and Hess, G.: An overview of the HYSPLIT_4 modelling system for trajectories, Aust. Meteorol. Mag., 47, 295308, 1998

Driscoll, C. T., Mason, R. P., Chan, H. M., Jacob, D. J., and Pirrone, N.: Mercury as a global pollutant: sources, path- ways, and effects, Environ. Sci. Technol., 47, 4967-4983, doi:10.1021/es305071v, 2013.

Ebinghaus, R., Kock, H. H., Temme, C., Einax, J. W., Löwe, A. G., Richter, A., Burrows, J. P., and Schroeder, W. H.: Antarctic springtime depletion of atmospheric mercury, Environ. Sci. Technol., 36, 1238-1244, doi:10.1021/es015710z, 2002.

Faïn, X., Obrist, D., Hallar, A. G., Mccubbin, I., and Rahn, T.: High levels of reactive gaseous mercury observed at a high elevation research laboratory in the Rocky Mountains, Atmos. Chem. Phys., 9, 8049-8060, doi:10.5194/acp-9-8049-2009, 2009.

Goodsite, M. E., Plane, J., and Skov, H.: A theoretical study of the oxidation of $\mathrm{Hg} 0$ to $\mathrm{HgBr}_{2}$ in the troposphere, Environ. Sci. Technol., 38, 1772-1776, doi:10.1021/es034680s, 2004.

Goodsite, M. E., Plane, J., and Skov, H.: Correction to a theoretical study of the oxidation of $\mathrm{HgO}$ to $\mathrm{HgBr}_{2}$ in the troposphere, Environ. Sci. Technol., 46, 5262-5262, doi:10.1021/es301201c, 2012.

Gratz, L. E., Ambrose, J. L., Jaffe, D. A., Shah, V., Jaeglé, L., Stutz, J., Festa, J., Spolaor, M., Tsai, C., Selin, N. E., Song, S., Zhou, X., Weinheimer, A. J., Knapp, D. J., Montzka, D. D., Flocke, F. M., Campos, T. L., Apel, E., Hornbrook, R., Blake, N. J., Hall, S., Tyndall, G. S., Reeves, M., Stechman, D., and Stell, M.: Oxidation of mercury by bromine in the subtropical Pacific free troposphere, Geophys. Res. Lett., 42, 10494 10502, doi:10.1002/2015GL066645, 2015a.

Gratz, L. E., Ambrose, J. L., Jaffe, D. A., Knote, C., Jaeglé, L., Selin, N. E., Campos, T. L., Flocke, F. M., Reeves, M., Stechman, D., Stell, M., Weinheimer, A. J., Knapp, D. J., Montzka, D. D., Tyndall, G. S., Mauldin, R. L., Cantrell, C. A., Apel, E., Hornbrook, R., and Blake, N. J.: Airborne observations of mercury emissions from the Chicago/Gary Urban/Industrial Area during the 2013 NOMADSS Campaign, AGU Fall Meeting, San Francisco, USA, 14-18 December 2015, B11D-0457, 2015b.

Gustin, M. S., Huang, J., Miller, M. B., Peterson, C., Jaffe, D. A., Ambrose, J., Finley, B. D., Lyman, S. N., Call, K., Talbot, R., Feddersen, D., Mao, H., and Lindberg, S. E.: Do we understand what the mercury speciation instruments are actually measuring? Results of RAMIX, Environ. Sci. Technol., 47, 7295-7306, doi:10.1021/es3039104, 2013.

Hall, B.: The gas phase oxidation of elemental mercury by ozone, Water Air Soil Poll., 80, 301-315, doi:10.1007/bf01189680, 1995.

Helsel, D. R.: Statistics for Censored Environmental Data Using Minitab and R, John Wiley and Sons, Hoboken, NJ, USA, doi:10.1002/9781118162729, 2011.

Holmes, C. D., Jacob, D. J., and Yang, X.: Global lifetime of elemental mercury against oxidation by atomic bromine in the free troposphere, Geophys. Res. Lett., 33, L20808, doi:10.1029/2006g1027176, 2006.

Holmes, C. D., Jacob, D. J., Corbitt, E. S., Mao, J., Yang, X., Talbot, R., and Slemr, F.: Global atmospheric model for mercury including oxidation by bromine atoms, Atmos. Chem. Phys., 10, 12037-12057, doi:10.5194/acp-10-12037-2010, 2010.

Huang, J., Miller, M. B., Edgerton, E., and Gustin, M. S.: Use of criteria pollutants, active and passive mercury sampling, and receptor modeling to understand the chemical forms of gaseous oxidized mercury in Florida, Atmos. Chem. Phys. Discuss., 15, 12069-12105, doi:10.5194/acpd-15-12069-2015, 2015. 
Hynes, A. J., Donohoue, D. L., Goodsite, M. E., and Hedgecock, I. M.: Our current understanding of major chemical and physical processes affecting mercury dynamics in the atmosphere and at the air-water/terrestrial interfaces, in: Mercury Fate and Transport in the Global Atmosphere, edited by: Mason, R. and Pirrone, N., Springer Science + Business Media, New York, NY, USA, 427-457, doi:10.1007/978-0-387-93958-2_14, 2009.

Karagas, M., Choi, A. L., Oken, E., Horvat, M., Schoeny, R., Kamai, E., Grandjean, P., and Korrick, S.: Evidence on the human health effects of low level methylmercury exposure, Environ. Health Persp., 120, 799-806, doi:10.3410/f.717797859.793302881, 2012.

Kos, G., Ryzhkov, A., Dastoor, A., Narayan, J., Steffen, A., Ariya, P. A., and Zhang, L.: Evaluation of discrepancy between measured and modelled oxidized mercury species, Atmos. Chem. Phys., 13, 4839-4863, doi:10.5194/acp-13-4839-2013, 2013.

Lamborg, C., Fitzgerald, W., Damman, A., Benoit, J., Balcom, P., and Engstrom, D.: Modern and historic atmospheric mercury fluxes in both hemispheres: global and regional mercury cycling implications, Global Biogeochem. Cy., 16, 51-1-51-11, doi:10.1029/2001gb001847, 2002.

Landis, M. S., Stevens, R. K., Schaedlich, F., and Prestbo, E. M.: Development and characterization of an annular denuder methodology for the measurement of divalent inorganic reactive gaseous mercury in ambient air, Environ. Sci. Technol., 36, 3000-3009, doi:10.1021/es015887t, 2002.

Landis, M. S., Lynam, M. M., and Stevens, R. K.: The monitoring and modelling of $\mathrm{Hg}$ species in support of local, regional and global modelling, in: Dynamics of Mercury Pollution on Regional and Global Scales, edited by: Pirrone, N. and Mahaffey, K., Springer Science + Business Media, New York, NY, USA, 123-151, doi:10.1007/0-387-24494-8_7, 2005.

Laurier, F. J., Mason, R. P., Whalin, L., and Kato, S.: Reactive gaseous mercury formation in the North Pacific Ocean's marine boundary layer: a potential role of halogen chemistry, J. Geophys. Res.-Atmos., 108, 4529, doi:10.1029/2003JD003625, 2003.

Lin, C.-J., Pongprueksa, P., Lindberg, S. E., Pehkonen, S. O., Byun, D., and Jang, C.: Scientific uncertainties in atmospheric mercury models I: Model science evaluation, Atmos. Environ., 40, 2911-2928, 2006.

Lin, J.-T. and McElroy, M. B.: Impacts of boundary layer mixing on pollutant vertical profiles in the lower troposphere: implications to satellite remote sensing, Atmos. Environ., 44, 17261739, doi:10.1016/j.atmosenv.2010.02.009, 2010.

Lin, S.-J. and Rood, R. B.: Multidimensional fluxform semi-Lagrangian transport schemes, Mon. Weather Rev., 124, 2046-2070, doi:10.1175/15200493(1996)124<2046:MFFSLT>2.0.CO;2, 1996.

Lindberg, S. E., Brooks, S., Lin, C.-J., Scott, K. J., Landis, M. S., Stevens, R. K., Goodsite, M., and Richter, A.: Dynamic oxidation of gaseous mercury in the Arctic troposphere at polar sunrise, Environ. Sci. Technol., 36, 1245-1256, doi:10.1021/es0111941, 2002.

Liu, H., Jacob, D. J., Bey, I., and Yantosca, R. M.: Constraints from $210 \mathrm{~Pb}$ and $7 \mathrm{Be}$ on wet deposition and transport in a global threedimensional chemical tracer model driven by assimilated meteorological fields, J. Geophys. Res.-Atmos., 106, 12109-12128, doi:10.1029/2000jd900839, 2001.
Lyman, S. N. and Jaffe, D. A.: Formation and fate of oxidized mercury in the upper troposphere and lower stratosphere, Nat. Geosci., 5, 114-117, doi:10.1038/ngeo1353, 2012.

Lyman, S. N., Jaffe, D. A., and Gustin, M. S.: Release of mercury halides from $\mathrm{KCl}$ denuders in the presence of ozone, Atmos. Chem. Phys., 10, 8197-8204, doi:10.5194/acp-10-81972010, 2010.

Mao, H., Talbot, R. W., Sive, B. C., Kim, S. Y., Blake, D. R., and Weinheimer, A. J.: Arctic mercury depletion and its quantitative link with halogens, J. Atmos. Chem., 65, 145-170, doi:10.1007/s10874-011-9186-1, 2010.

McClure, C. D., Jaffe, D. A., and Edgerton, E. S.: Evaluation of the $\mathrm{KCl}$ Denuder method for gaseous oxidized mercury using $\mathrm{HgBr}_{2}$ at an in-service AMNet site, Environ. Sci. Technol., 48, 1143711444, doi:10.1021/es502545k, 2014.

Mergler, D., Anderson, H. A., Chan, L. H. M., Mahaffey, K. R., Murray, M., Sakamoto, M., and Stern, A. H.: Methylmercury exposure and health effects in humans: a worldwide concern, AMBIO, 36, 3-11, doi:10.1579/00447447(2007)36[3:MEAHEI]2.0.CO;2, 2007.

Obrist, D., Tas, E., Peleg, M., Matveev, V., Faïn, X., Asaf, D., and Luria, M.: Bromine-induced oxidation of mercury in the mid-latitude atmosphere, Nat. Geosci., 4, 22-26, doi:10.1038/ngeo1018, 2011.

Pal, B. and Ariya, P. A.: Gas-phase HO-initiated reactions of elemental mercury: kinetics, product studies, and atmospheric implications, Environ. Sci. Technol., 38, 5555-5566, doi:10.1021/es0494353, 2004a.

Pal, B. and Ariya, P. A.: Studies of ozone initiated reactions of gaseous mercury: kinetics, product studies, and atmospheric implications, Phys. Chem. Chem. Phys., 6, 572-579, doi:10.1039/b311150d, 2004b.

Parrella, J. P., Jacob, D. J., Liang, Q., Zhang, Y., Mickley, L. J., Miller, B., Evans, M. J., Yang, X., Pyle, J. A., Theys, N., and Van Roozendael, M.: Tropospheric bromine chemistry: implications for present and pre-industrial ozone and mercury, Atmos. Chem. Phys., 12, 6723-6740, doi:10.5194/acp-12-6723-2012, 2012.

Pirrone, N., Cinnirella, S., Feng, X., Finkelman, R. B., Friedli, H. R., Leaner, J., Mason, R., Mukherjee, A. B., Stracher, G. B., Streets, D. G., and Telmer, K.: Global mercury emissions to the atmosphere from anthropogenic and natural sources, Atmos. Chem. Phys., 10, 5951-5964, doi:10.5194/acp-10-59512010, 2010.

Platt, U. and Stutz, J.: Differential Optical Absorption Spectroscopy, Physics of Earth and Space Environments, SpringerVerlag Berlin Heidelberg, Germany, doi:10.1007/978-3-54075776-4, 2008.

Ridley, B., Ott, L., Pickering, K., Emmons, L., Montzka, D., Weinheimer, A., Knapp, D., Grahek, F., Li, L., Heymsfield, G., McGill, M., Kucera, P., Mahoney, M. J., Baumgardner, D., Schultz, M., and Brasseur, G.: Florida thunderstorms: a faucet of reactive nitrogen to the upper troposphere, J. Geophys. Res.Atmos., 109, D17305, doi:10.1029/2004JD004769, 2004.

Rienecker, M., Suarez, M. J., Todling, R., Bacmeister, J., Takacs, L., Liu, H., Gu, W., Sienkiewicz, M., Koster, R., Gelaro, R., Stajner, I., and Nielsen, J. E.: The GEOS-5 Data Assimilation System-Documentation of Versions 5.0. 1, 5.1. 0, and 5.2.0, NASA Tech. Rep, NASA/TM-2008-104606, NASA Goddard Space Flight Center, Greenbelt, MD, USA, Vol. 27, 2008. 
Rutter, A., Shakya, K., Lehr, R., Schauer, J., and Griffin, R.: Oxidation of gaseous elemental mercury in the presence of secondary organic aerosols, Atmos. Environ., 59, 86-92, doi:10.1016/j.atmosenv.2012.05.009, 2012.

Scheuhammer, A. M., Meyer, M. W., Sandheinrich, M. B., and Murray, M. W.: Effects of environmental methylmercury on the health of wild birds, mammals, and fish, AMBIO, 36, 12-19, doi:10.1579/0044-7447(2007)36[12:EOEMOT]2.0.CO;2, 2007.

Selin, N. E.: Global biogeochemical cycling of mercury: a review, Annu. Rev. Env. Resour., 34, 43-63, doi:10.1146/annurev.environ.051308.084314, 2009.

Selin, N. E., Jacob, D. J., Park, R. J., Yantosca, R. M., Strode, S., Jaeglé, L., and Jaffe, D.: Chemical cycling and deposition of atmospheric mercury: global constraints from observations, J. Geophys. Res.-Atmos., 112, D02308, doi:10.1029/2006jd007450, 2007.

Selin, N. E., Jacob, D. J., Yantosca, R. M., Strode, S., Jaeglé, L., and Sunderland, E. M.: Global 3-D land-ocean-atmosphere model for mercury: present-day versus preindustrial cycles and anthropogenic enrichment factors for deposition, Global Biogeochem. Cy., 22, GB2011, doi:10.1029/2007GB003040, 2008.

Shepler, B. C., Balabanov, N. B., and Peterson, K. A.: $\mathrm{Hg}+\mathrm{Br} \rightarrow \mathrm{HgBr}$ recombination and collision-induced dissociation dynamics, J. Chem. Phys., 127, 164304, doi:10.1063/1.2777142, 2007.

Sheu, G.-R., Lin, N.-H., Wang, J.-L., Lee, C.-T., Yang, C.-F. O., and Wang, S.-H.: Temporal distribution and potential sources of atmospheric mercury measured at a high-elevation background station in Taiwan, Atmos. Environ., 44, 2393-2400, doi:10.1016/j.atmosenv.2010.04.009, 2010.

Sillman, S., Marsik, F. J., Al-Wali, K. I., Keeler, G. J., and Landis, M. S.: Reactive mercury in the troposphere: model formation and results for Florida, the northeastern United States, and the Atlantic Ocean, J. Geophys. Res.-Atmos., 112, D23305, doi:10.1029/2006jd008227, 2007.

Soerensen, A. L., Sunderland, E. M., Holmes, C. D., Jacob, D. J., Yantosca, R. M., Skov, H., Christensen, J. H., Strode, S. A., and Mason, R. P.: An improved global model for air-sea exchange of mercury: high concentrations over the North Atlantic, Environ. Sci. Technol., 44, 8574-8580, doi:10.1021/es102032g, 2010.

Sommar, J., Gårdfeldt, K., Strömberg, D., and Feng, X.: A kinetic study of the gas-phase reaction between the hydroxyl radical and atomic mercury, Atmos. Environ., 35, 3049-3054, doi:10.1016/s1352-2310(01)00108-x, 2001.

Song, S., Selin, N., Jaffe, D., Jaeglé, L., Gratz, L., Ambrose, J., Shah, V., and Giang, A.: Use of NOMADSS Observations to Improve Our Understanding of the Land and Ocean Fluxes of Mercury, AGU Fall Meeting, San Francisco, USA, 15-19 December 2014, A32A-07, 2014

Song, S., Selin, N. E., Soerensen, A. L., Angot, H., Artz, R., Brooks, S., Brunke, E.-G., Conley, G., Dommergue, A., Ebinghaus, R., Holsen, T. M., Jaffe, D. A., Kang, S., Kelley, P., Luke, W. T., Magand, O., Marumoto, K., Pfaffhuber, K. A., Ren, X., Sheu, G.-R., Slemr, F., Warneke, T., Weigelt, A., Weiss-Penzias, P., Wip, D. C., and Zhang, Q.: Top-down constraints on atmospheric mercury emissions and implications for global biogeochemical cycling, Atmos. Chem. Phys., 15, 7103-7125, doi:10.5194/acp-157103-2015, 2015.
Spicer, C., Satola, J., Abbgy, A., Plastridge, R., and Cowen, K.: Kinetics of Gas-Phase Elemental Mercury Reactions with Halogen Species, Ozone, and Nitrate Radical under Atmospheric Conditions, Final report to Florida Department of Environmental Protection, Battelle Memorial Institute, Columbus, OH, USA, 2002.

Sprovieri, F., Hedgecock, I. M., and Pirrone, N.: An investigation of the origins of reactive gaseous mercury in the Mediterranean marine boundary layer, Atmos. Chem. Phys., 10, 3985-3997, doi:10.5194/acp-10-3985-2010, 2010.

Strode, S., Jaeglé, L., and Emerson, S.: Vertical transport of anthropogenic mercury in the ocean, Global Biogeochem. Cy., 24, GB4014, doi:10.1029/2009gb003728, 2010.

Strode, S. A., Jaeglé, L., Selin, N. E., Jacob, D. J., Park, R. J., Yantosca, R. M., Mason, R. P., and Slemr, F.: Air-sea exchange in the global mercury cycle, Global Biogeochem. Cy., 21, GB1017, doi:10.1029/2006gb002766, 2007.

Subir, M., Ariya, P. A., and Dastoor, A. P.: A review of uncertainties in atmospheric modeling of mercury chemistry I. Uncertainties in existing kinetic parameters-Fundamental limitations and the importance of heterogeneous chemistry, Atmos. Environ., 45, 5664-5676, doi:10.1016/j.atmosenv.2011.04.046, 2011.

Sumner, A. L., Spicer, C. W., Satola, J., Mangaraj, R., Cowen, K. A., Landis, M. S., Stevens, R. K., and Atkeson, T. D.: Environmental chamber studies of mercury reactions in the atmosphere, in: Dynamics of Mercury Pollution on Regional and Global Scales, edited by: Pirrone, N. and Mahaffey, K., Springer Science + Business Media, New York, NY, USA, 193-212, doi:10.1007/0387-24494-8_9, 2005.

Swartzendruber, P., Jaffe, D., and Finley, B.: Development and first results of an aircraft-based, high time resolution technique for gaseous elemental and reactive (oxidized) gaseous mercury, Environ. Sci. Technol., 43, 7484-7489, doi:10.1021/es901390t, 2009.

Swartzendruber, P. C., Jaffe, D. A., Prestbo, E., Weiss-Penzias, P., Selin, N. E., Park, R., Jacob, D. J., Strode, S., and Jaeglé, L.: Observations of reactive gaseous mercury in the free troposphere at the Mount Bachelor Observatory, J. Geophys. Res.-Atmos., 111, D24301, doi:10.1029/2006jd007415, 2006.

Talbot, R., Mao, H., Scheuer, E., Dibb, J., and Avery, M.: Total depletion of $\mathrm{Hg}$ in the upper troposphere-lower stratosphere, Geophys. Res. Lett., 34, L23804, doi:10.1029/2007g1031366, 2007.

Tas, E., Obrist, D., Peleg, M., Matveev, V., Faïn, X., Asaf, D., and Luria, M.: Measurement-based modelling of bromine-induced oxidation of mercury above the Dead Sea, Atmos. Chem. Phys., 12, 2429-2440, doi:10.5194/acp-12-2429-2012, 2012.

Tossell, J.: Calculation of the energetics for the oligomerization of gas phase $\mathrm{HgO}$ and $\mathrm{HgS}$ and for the solvolysis of crystalline $\mathrm{HgO}$ and $\mathrm{HgS}$, J. Phys. Chem. A, 110, 2571-2578, doi:10.1021/jp056280s, 2006.

Travnikov, O., Lin, C., Dastoor, A., Bullock, O., Hedgecock, I., Holmes, C., Ilyin, I., Jaeglé, L., Jung, G., Pan, L., Pongprueksa, P., Ryzhkov, A., Seigneur, C., and Skov, H.: Global and regional modeling, in: Hemispheric Transport of Air Pollutants (HTAP) Assessment Report. Part B: Mercury, edited by: Pirrone, N. and Keating, T., UN-Economic Commission for Europe, Geneva, Switzerland, 97-144, 2010.

Wang, F., Saiz-Lopez, A., Mahajan, A. S., Gómez Martín, J. C., Armstrong, D., Lemes, M., Hay, T., and Prados-Roman, C.: Enhanced production of oxidised mercury over the tropical Pacific 
Ocean: a key missing oxidation pathway, Atmos. Chem. Phys., 14, 1323-1335, doi:10.5194/acp-14-1323-2014, 2014.

Wang, Q., Jacob, D. J., Fisher, J. A., Mao, J., Leibensperger, E. M., Carouge, C. C., Le Sager, P., Kondo, Y., Jimenez, J. L., Cubison, M. J., and Doherty, S. J.: Sources of carbonaceous aerosols and deposited black carbon in the Arctic in winter-spring: implications for radiative forcing, Atmos. Chem. Phys., 11, 12453 12473, doi:10.5194/acp-11-12453-2011, 2011.

Wang, S., Schmidt, J. A., Baidar, S., Coburn, S., Dix, B., Koenig, T. K., Apel, E., Bowdalo, D., Campos, T. L., Eloranta, E., Evans, M. J., DiGangi, J. P., Zondlo, M. A., Gao, R.-S., Haggerty, J. A., Hall, S. R., Hornbrook, R. S., Jacob, D., Morley, B., Pierce, B., Reeves, M., Romashkin, P., ter Schure, A., and Volkamer, R.: Active and widespread halogen chemistry in the tropical and subtropical free troposphere, P. Natl. Acad. Sci. USA, 112, 9281-9286, doi:10.1073/pnas.1505142112, 2015.

Wang, Y., Logan, J. A., and Jacob, D. J.: Global simulation of tropospheric $\mathrm{O}_{3}-\mathrm{NO}_{x}$-hydrocarbon chemistry: 2. Model evaluation and global ozone budget, J. Geophys. Res.-Atmos., 103, 1072710755, doi:10.1029/98jd00157, 1998.

Weiss-Penzias, P., Amos, H. M., Selin, N. E., Gustin, M. S., Jaffe, D. A., Obrist, D., Sheu, G.-R., and Giang, A.: Use of a global model to understand speciated atmospheric mercury observations at five high-elevation sites, Atmos. Chem. Phys., 15, 11611173, doi:10.5194/acp-15-1161-2015, 2015.
Wu, S., Mickley, L. J., Jacob, D. J., Logan, J. A., Yantosca, R. M., and Rind, D.: Why are there large differences between models in global budgets of tropospheric ozone?, J. Geophys. Res.-Atmos., 112, D05302, doi:10.1029/2006jd007801, 2007.

Zhang, L., Jacob, D. J., Downey, N. V., Wood, D. A., Blewitt, D., Carouge, C. C., van Donkelaar, A., Jones, D. B., Murray, L. T., and Wang, Y.: Improved estimate of the policyrelevant background ozone in the United States using the GEOS-Chem global model with $1 / 2 \times 2 / 3$ horizontal resolution over North America, Atmos. Environ., 45, 6769-6776, doi:10.1016/j.atmosenv.2011.07.054, 2011.

Zhang, Y., Jaeglé, L., van Donkelaar, A., Martin, R. V., Holmes, C. D., Amos, H. M., Wang, Q., Talbot, R., Artz, R., Brooks, S., Luke, W., Holsen, T. M., Felton, D., Miller, E. K., Perry, K. D., Schmeltz, D., Steffen, A., Tordon, R., Weiss-Penzias, P., and Zsolway, R.: Nested-grid simulation of mercury over North America, Atmos. Chem. Phys., 12, 6095-6111, doi:10.5194/acp12-6095-2012, 2012.

Zhang, Y., Jaeglé, L., Thompson, L., and Streets, D. G.: Six centuries of changing oceanic mercury, Global Biogeochem. Cy., 28, 1251-1261, doi:10.1002/2014gb004939, 2014. 